\title{
Lech Wołowski
}

\author{
Uniwersytet Papieski Jana Pawła II \\ ORCID: 0000-0003-2012-1267

\section{Mariologiczna interpretacja ośmiu błogosławieństw (Mt 5,3-10)}

\begin{abstract}
Abstrakt: Artykuł podejmuje kwestię mariologicznej interpretacji ośmiu błogosławieństw zawartych w Mt 5,3-10. Różnorodnych interpretacji tego biblijnego tekstu podejmowali się teolodzy chrześcijańscy wszystkich epok od Klemensa Aleksandryjskiego po autorów współczesnych komentarzy biblijnych. Wobec mnogości rozpatrywanych na przestrzeni dziejów interpretacji aspekt mariologiczny pojawia się dość rzadko. Tymczasem, jak zauważa papież Benedykt XVI, już sam biblijny tytuł maryjny "Błogosławiona" powinien wyraźnie nakierowywać myśl teologiczną na mariologiczne aspekty tego zagadnienia. W czasach współczesnych głęboką refleksję w tym zakresie prowadzili dwaj wielcy teologowie XX w. J. Ratzinger (Benedykt XVI) i H.U. von Balthasar. Na gruncie polskim zadanie to częściowo podjął J. Tischner, opracowując temat ośmiu błogosławieństw w kluczu maryjnej pielgrzymki narodu. W niniejszej pracy pragniemy pogłębić mariologiczno-biblijną analizę ośmiu błogosławieństw i ożywić dyskusję dotyczącą tej tematyki w zaproponowanym przez Benedykta XVI kluczu rozumienia błogosławieństw jako programu życia współczesnego chrześcijanina.
\end{abstract}

Słowa kluczowe: osiem błogosławieństw, mariologia, pielgrzymka, Benedykt XVI (Josef Ratzinger), Hans Urs von Balthasar, Józef Tischner

\section{Wstęp}

Celem niniejszej pracy jest przedstawienie mariologicznej interpretacji ośmiu błogosławieństw z Ewangelii wg św. Mateusza. Ze względu na to, że do tego zagadnienia można podejść z różnych stron, na początku należy wyjaśnić, z jakiego punktu widzenia problem będzie rozpatrywany.

Z jednej strony może się wydawać, że nie ma wystarczających podstaw do podjęcia takiego tematu. Nie tylko bowiem w ośmiu błogosławieństwach, ale w całym nawet szeroko pojętym Kazaniu na 
górze Jezus nigdy nie wymienia imienia Maryi ani w żaden sposób o niej nie wspomina. Trzymając się więc jedynie rozpatrywanego tu tekstu biblijnego (w tym przypadku Mt 5,3-10), rozumianego nawet w szerszym kontekście Kazania na górze (Mt 5,1-7,29), można by dojść do wniosku, że o mariologicznej interpretacji ośmiu błogosławieństw mowy być nie może.

Z drugiej strony można jednak na problem spojrzeć szerzej, tj. zgodnie z zasadą integralnej interpretacji Pisma Świętego. W takim świetle właściwe zrozumienie tego konkretnego fragmentu wymaga osadzenia go w całości Objawienia. Wielkim zwolennikiem tego podejścia, określanego mianem „metody kanonicznej”, jest Benedykt XVI. Teoretyczne aspekty stosowania tej metody w ramach katolickiej hermeneutyki biblijnej oraz powody, dla których zyskała ona wsparcie Magisterium Kościoła, przedstawia on w swej posynodalnej adhortacji Verbum Domini ${ }^{1}$. Jak natomiast w praktyce stosować tę metodę w rozważaniach nad tekstem biblijnym, nie mających ściśle egzegetycznego, lecz dogmatyczny charakter, pokazał on w swym monumentalnym dziele Jezus z Nazaretu ${ }^{2}$.

Jeżeli więc przyjmiemy takie podejście i jeśli spojrzymy na osiem błogosławieństw jako na ,program chrześcijańskiego życia”3, to nie ulega wątpliwości, że osobą, która program ten realizowała od strony praktycznej w sposób możliwie najpełniejszy (niekoniecznie formalnie uświadomiony), była właśnie Najświętsza Maryja Panna pierwsza i największa spośród świętych oraz ta, którą Pismo Święte

1 Zob. Benedykt XVI, Verbum Domini, 29-41. Szczegółowy przegląd metod interpretacji tekstów biblijnych i ich zastosowań w mariologii można znaleźć w: B.A. Buby, Biblical Methodology.

2 W przedmowie do tego dzieła papież powołuje się na tę metodę (zob. Benedykt XVI, Jezus z Nazaretu, cz. 1, 11), a następnie pokazuje, jak można stosować ją w analizach o charakterze dogmatycznym (z punktu widzenia tematu obecnej pracy kluczowe są tu rozdziały dotyczące Kazania na górze i głoszenia Ewangelii; zob. Benedykt XVI, Jezus z Nazaretu, cz. 1, 51-114). Na polu ściśle mariologicznym przykładem tego typu mariologicznej interpretacji tekstów biblijnych jest encyklika Jana Pawła II Redemptoris Mater (zwł. 7-24, 35-41; por. też Benedykt XVI, Verbum Domini, 27-28).

3 Dokładnie w ten sposób błogosławieństwa ujmuje B.T. Viviano w Katolickim Komentarzu Biblijnym: „Mateusz przekształca zatem krótki manifest mesjański w życiowy program”. B.T. Viviano, „Ewangelia według św. Mateusza”, 927). 
nazywa „błogosławioną”. Wyraźnie prawdę tę sformułował Paweł VI, który w swym uroczystym przemówieniu wygłoszonym 21 listopada 1964 r. na zakończenie III Sesji Soboru Watykańskiego II mówił:

W samym ziemskim życiu [Maryja] zrealizowała w sposób doskonały postać ucznia Chrystusowego, zwierciadło wszelkich cnót, urzeczywistniając w sobie ewangeliczne błogosławieństwa, wypowiedziane przez Jezusa Chrystusa. Słusznie więc cały Kościół, mimo iż gorliwość swoją wyraża różnorodnością form życia i działania, w Bogurodzicy Dziewicy upatruje osiągnięcie absolutnego przykładu doskonałego naśladowania Chrystusa. ${ }^{4}$

Mówił o tym także i Benedykt XVI w rozważaniu przed modlitwą Anioł Pański z dnia 30 stycznia 2011 r., kiedy podjął temat: Błogosławieństwa sa nowym programem życia i wystosował do zgromadzonych wiernych następującą zachętę: „Drodzy bracia i siostry, wzywajmy Maryję Pannę, Błogosławioną z samej swej istoty, prosząc Ją o siłę w szukaniu Pana (por. So 2,3) i w nieustannym postępowaniu za Nim z radością drogą Błogosławieństw"5.

4 Ponieważ wypowiedź ta bywa w literaturze bardzo różnie tłumaczona, przytaczamy wersję oryginalną: „In hac mortali vita perfectam Christi discipuli formam expressit, speculum fuit omnium virtutum, atque plene in suos rettulit mores beatitudines illas, quae a Christo Iesu praedicatae fuerunt. Quo fit, ut Ecclesia universa, dum multiformem suam vitam actuosamque suam navitatem explicat, a Deipara Virgine absolutissimum exemplum sumat, quo perfecte Christum imitari oporteat”. AAS 56 (1964), 1016.

5 Benedykt XVI, Błogosławieństwa. Dokładnie w tym samym duchu wypowiada się także Katechizm Kościoła Katolickiego: „Błogosławieństwa [...] wyjaśniają charakterystyczne działania i postawy życia chrześcijańskiego; są paradoksalnymi obietnicami, które podtrzymują nadzieję w trudnościach; zapowiadają dobrodziejstwa i nagrodę, które w sposób ukryty są już udzielane uczniom; zostały zapoczątkowane w życiu Najświętszej Mari Dziewicy i wszystkich świętych" (KKK, 1717). Jak widzimy postać Maryi pojawia się dość często w kontekście ośmiu błogosławieństw w Magisterium Kościoła - zarówno wypowiedziach papieży jak i dokumentach. Sytuacja ta nie znalazła jednakże dotychczas adekwatnego odzwierciedlenia w systematycznej refleksji teologicznej. Celem niniejszej pracy jest wypełnienie tej luki. 
W niniejszej pracy, idąc za wskazanym przez Magisterium Kościoła szerszym, tj. kanonicznym, ujęciem omawianego tu problemu oraz bez aspirowania do stworzenia opracowania o charakterze egzegetycznym, podejmiemy się przedstawienia współczesnej dogmatyczno-mariologicznej analizy biblijnego tekstu ośmiu błogosławieństw w świetle odpowiednich biblijnych tekstów mariologicznych. Zanim jednak będzie można przejść do sedna sprawy, należy jeszcze odpowiedzieć na pytanie, dlaczego postawiony tu problem jest aktualny i istotny dla współczesnej teologii.

Jest tak co najmniej z dwóch powodów. Pierwszy dotyczy korzyści jakie płyną z takiego podejścia dla samej mariologii. Zbyt często bowiem mariologia była i bywa do dziś uprawiana w oderwaniu od badań biblijnych. Refleksja nad mariologicznymi aspektami ośmiu błogosławieństw spełnia wszystkie postulaty, jakie swego czasu postawił przed biblijną odnową mariologii Józef Kudasiewicz: „Dlatego należy się z wiarą nachylać nad Bożym planem zbawienia, utrwalonym w Piśmie i szukać w nim śladów maryjnych; pytać, jakie miejsce zajmuje ona w Bożych planach zbawienia" . W tym samym duchu Charles Neumann, diagnozując przyczyny posoborowego spadku zainteresowania mariologią, postulował i przewidywał - powołując się na analizy Renégo Laurentina i Gérarda Philipsa - iż najbardziej obiecującym obszarem rozwoju mariologii w przyszłości (a zatem obecnej teraźniejszości) powinna być teologia biblijna ${ }^{7}$.

Po drugie podejście to jest bardzo ważne dla współczesnej antropologii chrześcijańskiej ${ }^{8}$. Jeżeli bowiem zgodzimy się z Benedyktem XVI, że osiem błogosławieństw wyznacza program życia chrześcijańskiego, to bezpośrednim wnioskiem z przyjęcia tego założenia jest to, że ich mariologiczna interpretacja staje się bardzo ważnym głosem dotyczącym kwestii tożsamości i miejsca chrześcijanina w ogólności, a kobiety w szczególności, we współczesnym Kościele i świecie?.

6 J. Kudasiewicz, [wypowiedź w:] Biblijna droga, 16.

7 Por. C.W. Neumann, „The Decline of Interest”, 26.

$8 \mathrm{Na}$ aspekt ten wielokrotnie zwracał uwagę w swych rozlicznych pracach R. Laurentin, którego wkład w tym zakresie podsumowuje: C.W. Neumann, „The Decline of Interest", 27-29.

9 Oczywiście sama mariologiczno-biblijna dyskusja na temat miejsca kobiety w Kościele i świecie nie jest niczym nowym. Podejmowana była już lata temu 
Warto zwrócić uwagę na jeszcze inny aspekt o charakterze duszpastersko-pastoralnym. Peter Casarella w swej pracy poświęconej analizie listu apostolskiego Jana Pawła II, Rosarium Virginis Mariae, w którym papież wprowadza do rozważań różańcowych nową część, poświęconą tzw. tajemnicom światła, podkreśla jak ważną rolę w procesie nowej ewangelizacji powinny pełnić rozważania różańcowe:

Odwołując się do ulubionego przez papieża obrazu apostołów przygotowujących się do roli rybaków ludzi, list o różańcu jest czymś w rodzaju odprawy dla tych, którzy mają ,wypłynąć na głębię" (duc in altum), by mogli sprostać wymogom ewangelizacji w nowym milenium chrześcijaństwa (por. Rosarium Virginis Mariae, 24). Różaniec może służyć głosicielom nowej ewangelizacji, ponieważ stanowi „kompendium całej Ewangelii” (Rosarium Virginis Mariae, 1). ${ }^{10}$

Dlatego pod koniec pracy, jako podsumowanie i jednocześnie zastosowanie rezultatów przeprowadzonych badań, rozwinięty zostanie wątek refleksji nad trzecią tajemnicą światła, ściśle związaną

(A. Feuillet, Jésus et sa mère) i kontynuowana zarówno na gruncie międzynarodowym (B. Rinaldi, Madonna) jak i polskim (W. Życiński, Matka, 137-159). Wciąż brakuje jej jednak należytej dynamiki i kierunku. Stąd obecna propozycja ożywienia jej nowym wątkiem, dotyczącym mariologii ośmiu błogosławieństw. Warto jednak wspomnieć, że w ostatnich latach istotny wkład w tę dyskusję wniosła Gloria Dodd. Zwróciła ona uwagę badaczy na fundamentalne dla mariologii rozróżnienie na dwa nurty: nawiązujący do czasów rewolucji lat 60. feminizm i oparty na nauczaniu Pawła VI i Jana Pawła II nowy feminizm (zob. G.F. Dodd, „Feminist and New Feminist”, 279-280). Autorka dokonuje wnikliwej analizy obu tych podejść, wskazując na istotne różnice w spojrzeniu na osobę Maryi przedstawicielek obu tych nurtów, a co za tym idzie, na kształtowanie się dwóch odmiennych wizji antropologii (por. G.F. Dodd, „Feminist and New Feminist”, 290-294). W kontekście rozróżnienia obu tych nurtów warto postawić pytanie: jeżeli wezwanie Jana Pawła II do nowej ewangelizacji spotkało się z tak żywym odzewem na całym świecie, to dlaczego jego wezwanie do nowego feminizmu (zawarte w encyklice Evangelium Vitae, 99) zostało praktycznie niezauważone? Jeżeli tak często Maryję określa się mianem „Gwiazdy nowej ewangelizacji”, to wydaje się, że uwagę badaczy powinna przykuwać również jej rola jako „Gwiazdy nowego feminizmu”.

10 P. Casarella, „Contemplating Christ”, 163. 
z ośmioma błogosławieństwami poprzez zagadnienie głoszenia Królestwa Bożego ${ }^{11}$.

I wreszcie ostatnia kwestia, ale z pewnością nie najmniej ważna. Jak słusznie zauważa Scott Hahn, w czasach dzisiejszej wszechobecnej specjalizacji mariologiczne spojrzenie na zagadnienia biblijne pozwala teologom wydostać się z ciasnych prowincji ich wąskich pól zainteresowania i wypłynąć na szerokie wody uniwersalizmu Kościoła. Nawiązując do diagnozy Jacques’a Barzuna, dotyczącej postępującej w nauce „choroby specjalizmu” (ang. disease of specialism) ${ }^{12}$, Hahn dzieli się z czytelnikiem następującym spostrzeżeniem, które dobrze wpisuje się także w charakter niniejszej pracy:

Barzun narzeka, że dziś: „Ekspert obiera sobie za swą prowincję jakiś drobny temat - i na całe życie zostaje człowiekiem z prowincji”. [...] A jednak, gdzieś daleko na naszych prowincjach, coś pociągnęło nas i podprowadziło do Miriam z Nazaretu - kobiety z prowincji. A w spotkaniu z nią przed naszymi oczami otworzył się szeroki świat. Bo w niej, bardziej niż w jakiejkolwiek innej rzeczywistości ludzkiej, to co prowincjonalne staje się uniwersalne. [...] Być może jest tak dlatego, że Maryja jest archetypem macierzyństwa, a właściwą rolą matki jest gromadzenie jej rozproszonych dzieci. [...] $\mathrm{Z}$ tego i wielu innych powodów uważam, że mariologia, być może bardziej niż jakakolwiek inna dziedzina, może dostarczyć antidotum na teologiczną odmianę syndromu Barzuna

11 P. Casarella często nawiązuje w swej pracy do motywu „szkoły Maryi”, w której kształcą się uczniowie Chrystusa (zob. P. Casarella, „Contemplating Christ”, 163-172). Ważnym przykładem zastosowania rozważań zawartych w niniejszej pracy może być więc kwestia katechetycznego aspektu ,szkoły Maryi opisywanej w Piśmie Świętym i przez Tradycję", który analizował Piotr Tomasik, zwracając m.in. uwagę na konieczność biblijnego osadzenia podejmowanych na katechezie mariologicznych kwestii (por. P. Tomasik, „Katecheza maryjna”, 159). Analizy zawarte w niniejszym artykule dostarczają bogatego materiału, który - po odpowiedniej adaptacji - może posłużyć jako baza do przygotowania cyklu katechez/ homilii maryjnych spełniającej postulowane w tym opracowaniu kryteria.

12 Zob. J. Barzun, The Culture, 6-7. 
- [...] może zebrać w jedno rozproszone dyscypliny poprzez modelowanie integrującego je podejścia całościowego. ${ }^{13}$

\section{Status quaestionis}

Tematyka ośmiu błogosławieństw zawartych w Mt 5,3-10 inspirowała teologów od pierwszych wieków chrześcijaństwa. Tradycję komentarzy do tego sławnego tekstu biblijnego rozpoczął w swych Kobiercach Klemens Aleksandryjski ${ }^{14}$. W połowie III w. zagadnienie to podjął też Orygenes w swoim obszernym komentarzu do Ewangelii wg św. Mateusza. Niestety pierwsze dziewięć ksiąg tego komentarza - poświęconych zapewne w znacznej mierze Kazaniu na górze - zaginęło ${ }^{15}$. Pierwszym w całości zachowanym i poświęconym w pełni tej tematyce dziełem patrystycznym są Homilie do błogosławieństw Grzegorza z Nyssy ${ }^{16}$. Niedługo po Grzegorzu swój sławny komentarz do ośmiu błogosławieństw napisał Augustyn ${ }^{17}$.

13 S. Hahn, „Biblical Theology”, 9-10.

14 Klemens podporządkowuje temat błogosławieństw rozważanemu przez siebie szerszemu problemowi męczeństwa. Wychodząc od fizycznych aspektów męczeństwa (głód, ubóstwo, cierpienie, smutek), stara się położyć główny nacisk na nadprzyrodzonej motywacji do podejmowania tych trudów (błogosławieni prześladowani dla sprawiedliwości). Błogosławieństwa są tu podjęciem drogi ascezy i stopniowym wznoszeniem się duszy do Boga (zob. Klemens Aleksandryjski, Kobierce, t. I, Kobierzec IV, cz. I: O Męczeństwie, p. b) O błogosławieństwach, 25-41).

15 Por. E. Stanula, Wprowadzenie, w: Orygenes, Komentarz do Ewangelii, 6.

${ }_{16}$ Grzegorz z Nyssy, Homilie do błogosławieństw. W dziele tym Grzegorz podejmuje rozpoczęty przez Klemensa motyw wznoszenia się duszy do Boga i proponuje schemat rozumienia ośmiu błogosławieństw jako poszczególnych szczebli, po których człowiek, niczym po „drabinie Jakubowej”, konsekwentnie pnie się ku niebu, czyli ku prawdziwemu szczęściu, które Grzegorz rozumie jako partycypację człowieka w życiu Boga (zob. Homilia I, 33).

17 Augustyn z Hippony, O kazaniu Pana na Górze (De sermone Domini in monte). W komentarzu tym Augustyn dokonał oryginalnego zestawienia ośmiu błogosławieństw (Mt 5,3-10) z siedmioma darami Ducha Świętego (por. Iz 11,1-2) oraz z siedmioma wezwaniami modlitwy Pańskiej „Ojcze nasz” (Mt 6,9-13). Czytelnika zainteresowanego głębszą analizą tego zestawienia odsyłamy do S.T. Pinckaers, Komentarz św. Augustyna, 145-164. 
Na przestrzeni wieków zarówno wielu Ojców Kościoła, średniowiecznych scholastyków, jak również współczesnych komentatorów Pisma Świętego starało się w swych badaniach pogłębiać studium nad tą tematyką. Refleksja patrystyczna była zazwyczaj głęboko osadzona biblijnie, jednak mało było w niej odniesień maryjnych w interesującym nas zakresie. Choć od średniowiecza do renesansu pobożność maryjna uległa prawdziwemu rozkwitowi, to wątek biblijny zdecydowanie zdominowany został przez styl homiletyczno-modlitewny ${ }^{18}$.

Warto się zastanowić, czy czasy współczesne przyniosły jakąś równowagę w tym zakresie. Trudno o jednoznaczną odpowiedź. $\mathrm{Z}$ jednej strony, jeśli będziemy rozpatrywać błogosławieństwa osobno, niemal każdemu z nich przyporządkować można jakąś współczesną mariologiczną monografię ${ }^{19}$. Z drugiej, jeżeli uzna się osiem błogosławieństw za nierozerwalną całość i weźmie się pod uwagę współczesne komentarze biblijne do tego tekstu, to w zdecydowanej większości o aspekcie mariologicznym będą one milczeć ${ }^{20}$.

Istnieją jednakże opracowania, które wprawdzie explicite mariologiczną interpretacją ośmiu błogosławieństw się nie zajmują, ale można ją z nich, przynajmniej częściowo, odczytać ${ }^{21}$. Wartościowe są tu w szczególności biblijno-mariologiczne badania i opracowania

18 Krótką charakterystykę mariologiczną tego okresu znaleźć można w: K. Kowalik, „Piąty dogmat?”, 81-99. Aspekt homiletyczno-modlitewny średniowiecznej twórczości mariologicznej został przeanalizowany np. w: N.M. Siwiński, „Rogamus te", 91-145.

19 Dla przykładu za monografię poświęconą maryjnemu aspektowi pierwszego błogosławieństwa może być uznana np. praca: Ł. Samiec, Maryja. Problem w tym, że bardzo często, omawiając tę tematykę, komentatorzy koncentrują się na nie tym aspekcie ubóstwa, na który tak naprawdę błogosławieństwo to wskazuje.

${ }^{20}$ Także jedynie przykładowo wystarczy zauważyć, że we współczesnym komentarzu do Ewangelii wg św. Mateusza Silvano Fausti SJ wymienia siedem kluczowych aspektów, w świetle których jego zdaniem można odczytywać omawiany tu tekst: chrystologiczny, teologiczny, antropologiczny, soteriologiczny, eklezjologiczny, eschatologiczny i moralny. Na osobne potraktowanie aspektu mariologicznego, jak widać zabrakło tu miejsca (zob. S. Fausti, Wspólnota czyta Ewangelię, 68).

${ }^{21}$ Wśród tego rodzaju prac wato wymienić: H. Rondet, Maria nel disegno; B. Häring, Pieśń stugi. 
takich autorów jak Aristide Serra, Stefano Manelli czy Hugolin Langkammer ${ }^{22}$.

Ze względu na dogmatyczny charakter niniejszej pracy, na wyjątkową uwagę zasługiwać będzie wydana wspólnie przez dwóch gigantów teologii współczesnej, tj. Hansa Ursa von Balthasara i Josepha Ratzingera, praca pt.: Maryja w tajemnicy Kościoła. Szczególnie interesująca będzie refleksja Ratzingera (Benedyka XVI), który sporo miejsca w swych badaniach poświęca tytułom „,błogosławiona” i „łaski pełna”, które to z kolei wskazują na szczególną łączność pomiędzy charytologią, mariologią oraz zagadnieniem błogosławieństw. Ratzinger podkreślał centralny dla charytologii mariologiczny aspekt drogi do zbawienia, którą kroczy chrześcijanin, a która w tej pracy zinterpretowana będzie jako maryjna droga ośmiu błogosławieństw:

Należyte zrozumienie znaczenia znaku Bożego w narodzeniu z Dziewicy wskazuje zarazem miejsce, jakie zajmuje w teologii nabożeństwo do Najśw. Marii Panny, które można wyprowadzić z wiary Nowego Testamentu. [...] Jeżeli chcielibyśmy wskazać, do jakiego traktatu teologicznego należy mariologia jako jego konkretyzacja, to byłaby nim najprędzej nauka o łasce, która oczywiście stanowi całość z eklezjologią i antropologią. Jako prawdziwa „córka Syjonu” jest Maria obrazem Kościoła, obrazem człowieka wierzącego, który nie inaczej, niż tylko przez dar miłości - przez łaskę - może dojść do zbawienia i stać się sobą samym. ${ }^{23}$

Nie można także nie wspomnieć o rodzimym dorobku. Wprawdzie nie w kontekście samych błogosławieństw, lecz ogólnie na tle Nowego Testamentu, problematykę Maryi jako „błogosławionej” podjął Feliks Gryglewicz ${ }^{24}$. Jeżeli jednak chodzi o konkretny temat

22 Zob. A.M. Serra, E c'era la Madre; S.M. Manelli, Mariologia biblica lub S.M. Manelli, All generations oraz H. Langkammer, Maryja w Nowym Testamencie.

23 J. Ratzinger, Wprowadzenie w chrześcijaństwo, 274; por. także. J. Ratzinger, H.U. von Balthasar, Maryja w tajemnicy Kościoła, 53-60. Jak widać do tytułów „błogosławiona” i „łaski pełna” dochodzi jeszcze tytuł „córka Syjonu”. Wszystkie te tytuły będą stanowiły istotne elementy budulcowe naszej analizy.

24 Zob. F. Gryglewicz, Błogosławiona. 
obecnej pracy, to na wyjątkową uwagę zasługuje (dziś już niemal całkowicie zapomniany) komentarz, jaki w kluczu maryjnej pielgrzymki narodu opracował Józef Tischner ${ }^{25}$. Ciekawy jest już sam fakt, że Tischner, który omawianą tu tematyką bezpośrednio się nie zajmował, pozostawił po sobie mariologiczny komentarz do ośmiu błogosławieństw. Odwołał się przy tym do obrazu pielgrzymki, który $\mathrm{z}$ etymologicznego punktu widzenia wyjątkowo dobrze pasuje do tej problematyki ${ }^{26}$.

Zaproponowane w Tischnerowskiej refleksji połączenie motywu pielgrzymki, Maryi i ośmiu błogosławieństw wydaje się posiadać charakter ponadczasowy i stało się jednym z głównych impulsów podjęcia niniejszych badań. Zapożyczony od Tischnera wątek pielgrzymki, rozważany w kontekście ośmiu błogosławieństw, nie jest więc aspektem oryginalnym, niemniej jednak jest bardzo ważnym rysem charakterystycznym niniejszej pracy.

Pod względem oryginalności ważniejszy będzie natomiast inny aspekt. Błogosławieństwa zostały określone przez Katechizm Kościoła Katolickiego mianem ,,paradoksalnych obietnic"27. Jeżeli Maryja w swoim życiu zrealizowała te błogosławieństwa w przykładowy sposób, to siłą rzeczy sama musiała przez paradoksy te przebrnąć. Muszą one przebijać przez różne aspekty jej życia, muszą być widoczne w tekstach biblijnych, które to opisują.

Jako jedną z nielicznych refleksji wychwytujących tego typu aspekt paradoksalności w mariologii warto wymienić podejście reprezentowane przez Aarona Richesa. Wprawdzie i tym razem nie bezpośrednio w kontekście ośmiu błogosławieństw, a w ramach problematyki niepokalanego poczęcia i zwiastowania, dostrzegł on

25 Zob. J. Tischner, Książeczka pielgrzyma.

26 Warto w tym miejscu zauważyć, że odpowiednikiem użytego w Ewangelii greckiego przymiotnika makárioi jest hebrajskie 'ašrê (zob. B.T. Viviano, „Ewangelia według św. Mateusza”, 926), którego rdzeń znaczeniowy - obok „,być szczęśliwym” - obejmuje takie kategorie jak „rozkwitać” i ,prosperować”, czyli „rozwijać się”, ,iść do przodu”, ,czynić postępy w drodze”- wszystko oczywiście pod Bożym błogosławieństwem - a stąd niedaleko już do ,,pielgrzymować” (odpowiednie etymologiczne studium nad znaczeniami 'ašrê / makárioi można znaleźć w: I.J. Van der Merwe, „Biblical happiness”, 697-704).

27 KKK, 1717. 
mariologiczno-chrystologiczny paradoks tzw. ,refleksywnej cykliczności" (ang. reflexive circularity): jej niepokalane fiat zanurzone jest w poprzedzającym je, bo odwiecznym, kenotycznym „tak”, jakie Syn Boży wypowiada wobec Ojca. Paradoks polega na tym, że realizacja fiat Syna, które poprzedza i umożliwia niepokalane fiat Maryi, jest sama tym maryjnym fiat uwarunkowana ${ }^{28}$.

Właśnie ten aspekt paradoksalności będzie naświetlony i podkreślony w niniejszej pracy. Można bowiem śmiało postawić tezę, że w przypadku mariologicznego spojrzenia na problem ośmiu błogosławieństw mamy do czynienia z podobnym zjawiskiem „,refleksywnej cykliczności”. Maryja już realizuje w swoim życiu ideał ośmiu błogosławieństw, zanim Chrystus zdąży wygłosić je podczas Kazania na górze (nie wiadomo nawet, czy kiedykolwiek o nich słyszała). Realizacją tych błogosławieństw jest kenotyczne zanurzenie się w Chrystusie, które - na wzór Jego kenozy poprzedzającej wszystko - nie może obfitować w nic innego jak właśnie w paradoksy ${ }^{29}$.

Na ten aspekt mariologii, choć niekoniecznie explicite ujmowany w kategorii paradoksu, wyczuleni są również tacy autorzy jak wspomniani już wyżej Balthasar, Ratzinger i Tischner. Do nich więc najczęściej nawiązywać będą poniższe analizy.

\section{2. „Błogosławiona”, „szczęśliwa” i „łaski pełna”}

Wspomnieliśmy wyżej, że Ratzinger powiązał tematykę ośmiu błogosławieństw z aspektem mariologicznym poprzez biblijny tytuł maryjny „błogosławiona" ${ }^{30}$. Skojarzenie to wymaga uzasadnienia i doprecyzowania. W popularnym w Polsce przekładzie Biblii Tysiaclecia ${ }^{31}$ tytuł „błogosławiona” pojawia się w ramach Nowego

28 Zob. A. Riches, „Deconstructing the linearity”, 180.

29 Balthasar formułuje zbliżoną obserwację: ,,Jeżeli życie Syna ukazywane jest jako coraz głębsza kenoza, to życie Matki okazuje się wiernym towarzyszeniem”. H.U. von Balthasar, Medytacja chrześcijańska, 58.

30 Podobnie zresztą uczynił Tischner, który w swym komentarzu pisał: „Ona pierwsza została nazwana «błogosławioną», do Niej więc nawiązują pośrednio Błogosławieństwa”. J. Tischner, Książeczka pielgrzyma, 49.

31 Jeżeli nie zaznaczamy inaczej, cytaty biblijne podajemy za Biblia Tysiąclecia (wyd. 5). Tam, gdzie odwołujemy się do greckiego oryginału i tłumaczenia 
Testamentu w różnych kontekstach i w wersji oryginalnej odpowiadają mu różne terminy greckie, nie zawsze tożsame z kluczowym

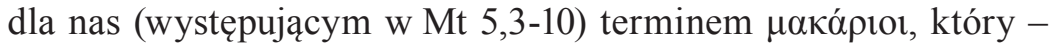
w dokładnym tłumaczeniu na język polski - oddany powinien być terminem „,szczęśliwi”32. W najczęściej recytowanym biblijnym wersecie, w którym Elżbieta nazywa Maryję „,błogosławioną” (Łk 1,42),

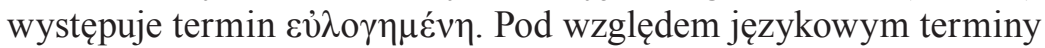
te dobrze do siebie pasują. Chwilowo tracimy jednak z oczu łączność z $\mu \alpha \kappa \alpha ́ \rho ı 1$.

Żeby tę łączność odzyskać, należy odwołać się do dalszych wersetów jeszcze w ramach tej samej wypowiedzi Elżbiety. Maryja nazywana jest tam $\mu \alpha \kappa \alpha \rho i ́ \alpha ~(Ł k ~ 1,45)$ a zatem ,szczęśliwa”. Tytuł ten sama następnie potwierdza w pieśni Magnificat (Łk 1,48) ${ }^{33}$. Pomimo więc pewnych nieścisłości, jakie zachodzą w popularnych tłumaczeniach, nie ulega wątpliwości, że Biblia określa Maryję tym samym tytułem, jaki użyty został w ośmiu błogosławieństwach wypowiedzianych w Mt 5,3-10.

Warto dodać, że spotkanie Maryi i Elżbiety nie jest jedynym ewangelicznym kontekstem, w którym Pismo Święte obdarza Maryję tytułem $\mu \alpha \kappa \alpha \rho i ́ \alpha$. Bardzo ciekawy pod tym względem jest „epizod” z tzw. anonimową niewiastą z tłumu ( Łk 11,27-28). Interesujący nas termin odniesiony tam do Maryi można interpretować w podwójnym sensie. Po pierwsze w kontekście jej Bożego Macierzyństwa: „Szczęśliwe łono ( $\mu \alpha \kappa \alpha \rho i ́ \alpha$ ๆ $\kappa o \imath \lambda i ́ \alpha)$, które nosiło cię, i piersi, które ssałeś”, po drugie w kontekście słuchania i przestrzegania Słowa

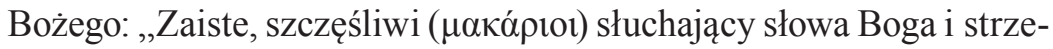
gący [go]"34. Istotny jest zwłaszcza ten drugi człon, w którym w ściśle

interlinearnego, korzystamy z: Grecko-polski Nowy Testament, R. Popowski, M. Wojciechowski (tłum.) (dalej GPNT).

32 GPNT, 15.

33 W kwestii dalszych szczegółów natury egzegetycznej, dotyczących różnic w tytułach maryjnych występujących w Łk 2,42 i Łk 2,45; zob. B. Adamczewski, „Szczęśliwa, która uwierzyła”, 75-87.

34 Cytaty za GPNT, 311. Więcej na temat wspomnianej tu interpretacji w: J. Kudasiewicz, [wypowiedź w:] Biblijna droga, 41-45; B. Adamczewski, ,Szczęśliwa, która uwierzyła”, 84-87 oraz L. Wołowski, ,Słowo o syntezie”, 254-263. 
mariologicznym kontekście pada z ust samego Jezusa to samo słowo, które wypowiada On w ośmiu błogosławieństwach.

Choć już nie tak bezpośredni, to wciąż istotny związek zachodzi także między mariologiczno-charytologicznym tytułem ,,taski

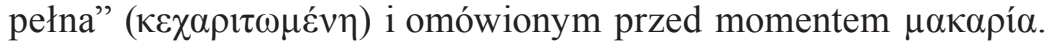
Tytuł „łaski pełna” wprowadzony jest bowiem w scenie zwiastowania (Łk 1,28) sugestywnym pozdrowieniem ,raduj się”: $\chi \alpha$ ĩ $\rho \varepsilon$, $\kappa \varepsilon \chi \alpha \rho \imath \omega \mu \varepsilon^{\prime} \vee \eta$ („,raduj się, napełniona łaską”) ${ }^{35}$.

Nie chcemy zagłębiać się tutaj w szczegółowe rozważania natury etymologicznej, na potrzeby niniejszej pracy wystarczy zauważyć,

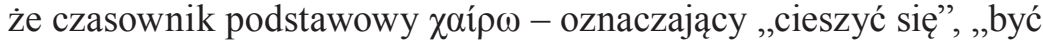
zadowolonym”, „radować się ogromnie"36 i będący rdzeniem słowo-

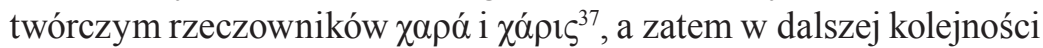
czasownika $\chi \alpha \rho \imath$ ó $\omega$ i wreszcie omawianego tu $\kappa \varepsilon \chi \alpha \rho \imath \tau \omega \mu \varepsilon ́ v \eta^{38}-$ wskazuje na głęboko zakorzeniony w polu semantycznym tego tytułu pierwiastek radości ${ }^{39}$.

Wezwanie do radości wypowiedziane pod adresem Maryi przez

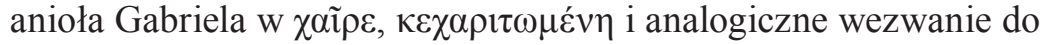

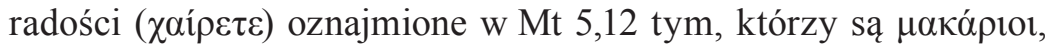
staje się w tych okolicznościach bezpośrednim łącznikiem pomiędzy

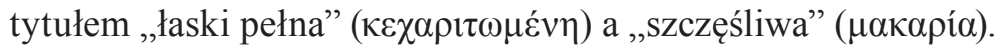

Od strony mariologiczno-dogmatycznej wielostronną analizę tytułu ,łaski pełna” przeprowadził Ratzinger ${ }^{40}$.

\section{Analiza poszczególnych błogosławieństw w kluczu współczesnej refleksji biblijno-mariologicznej}

Poniżej prześledzimy po kolei osiem błogosławieństw i zaproponujemy ich współczesną mariologiczną interpretację. Za każdym razem rozpatrywana będzie seria maryjnych tekstów biblijnych,

\footnotetext{
35 GPNT, 239.

36 Zob. J. Strong, Grecko-polski stownik, 825.

37 Tamże, 827-828.

38 Tamże, 829.

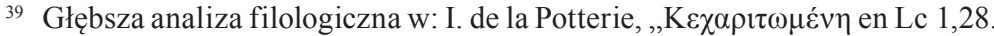
Étude philologique”. Warto skonsultować też: F. Rossier, „Kecharitomene (Lk. 1:28)”.

40 Zob. J. Ratzinger, H.U. von Balthasar, Maryja w tajemnicy Kościoła, 53-69. 
które następnie odniesione zostaną do danego błogosławieństwa. Ze względu na dogmatyczny charakter zamieszczonych tu rozważań omawiane teksty będą opatrzone teologicznym komentarzem - będzie on miejscami skonfrontowany z myślą współczesnych biblistów i mariologów, jednak w szczególny sposób uwzględniona zostanie tu myśl Ratzingera, Balthasara i Tischnera.

\section{1. „Błogosławieni ubodzy w duchu” (Mt 5,3)}

Problematyka ubóstwa łączy w sobie dwa punkty widzenia, z których warto spojrzeć na omawiane tu błogosławieństwo: chodzi o aspekt maryjny i aspekt pielgrzymki.

Teksty biblijne, w których jest najlepiej widoczne, jak Maryja przeżywa swe ubóstwo, związane są właśnie z jej pielgrzymowaniem. Tekstów tych jest wiele, na przykład: pielgrzymka górska w drodze na spotkanie z Elżbietą (Łk 1,39-40), pielgrzymka na spis do Betlejem (Łk 2,1-7), pielgrzymka ucieczki do Egiptu (Mt 2,13-15), coroczne pielgrzymki do Jeruzalem (Łk 2,41-51). Patrząc na bogactwo tych tekstów, można dojść do wniosku, że wątek ubóstwa Maryi jest znaczeniowo bardzo bogaty. Nie chodzi tu bowiem tylko o ubóstwo w sensie braków materialnych, choć i to doświadczenie nie było Maryi obce, o czym świadczy wyraźnie drugi z tych tekstów. Dla osoby zamożnej nie zabrakłoby miejsca w gospodzie i nie musiałaby układać nowonarodzonego dziecka w żłobie. Nie ten aspekt będzie tu jednak najważniejszy.

Niezależnie od egzegetycznych hipotez stanowiących o dodaniu przez Mateusza słów dotyczących duchowego charakteru ubóstwa, o którym mówi pierwsze błogosławieństwo ${ }^{41}$, tekst biblijny Mt 5,3, który przyjął taką właśnie formę (oi $\pi \tau \omega \chi 0 i ̀ ~ \tau \tilde{\omega} \pi v \varepsilon v ́ \mu \alpha \tau 1$ - „biedni duchem"42), wyraźnie zachęca do tego, by ubóstwa, o którym tu mowa, nie sprowadzać tylko do kwestii niedostatków materialnych. Dokładnie ta sama sytuacja zachodzi w przypadku ubóstwa Maryi: nie chodzi w nim (tylko) o to, że nie miała odpowiednich ubranek dla Dzieciątka Jezus i miejsca, w którym mogłaby Je położyć (Łk 2,7).

41 Zob. B.T. Viviano, „Ewangelia według św. Mateusza”, 926.

42 GPNT, 15. 
Duchowy wymiar ubóstwa różnie był przez komentatorów rozumiany. Aleksy Klawek w swych rozważaniach na temat tego błogosławieństwa sugeruje, że polegało ono na dobrowolnym przyjęciu stanu ubóstwa materialnego. Aspekt duchowy ograniczałby się tu więc tylko do tego, że adresaci omawianego błogosławieństwa: „«W duchu», czyli aktem woli zgadzali się ze swym położeniem"43.

Dużo dalej w swych analizach zachodzi Serra. Odpowiednik Mateuszowych ,ubogich w duchu” ( $\pi \tau \omega \chi 0 \grave{~} \tau \tilde{\omega} \pi v \varepsilon v ́ \mu \alpha \tau)$ upatruje on

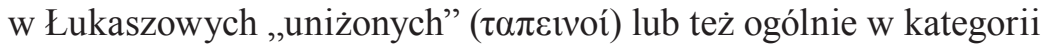
„uniżenia” ( $\tau \alpha \pi \varepsilon i ́ v \omega \sigma ı \varsigma)$, o której mowa w Magnificat (Łk 1,48.52) ${ }^{44}$. Korzeni idei „ubóstwa w duchu” szuka on w hebrajskiej kategorii 'anāwîm i odnajduje w postawie bohaterów późno-starotestamentalnych ksiąg (Jdt, Est, 1-2 Mch, Dn). 'Anāwîm to ludzie nie tylko ubodzy materialnie i uciskani przez oprawców. To przede wszystkim ci, którzy korzą się przed Bogiem, pozostają posłuszni i wierni Jego przymierzu i uciekają się do Niego w pokornej modlitwie ${ }^{45}$. Przekładając te obserwacje na realia Nowego Testamentu, Serra wyciąga ciekawy wniosek - oparty zarówno na tradycji patrystycznej, jak i na badaniach biblijnych - że podstawowym przejawem duchowego ubóstwa Maryi było jej fiat. Ta obserwacja połączona z analizą hymnu Magnificat prowadzi go do konkluzji, że „ubogość w duchu” sług bożych jest „płodną przestrzenią”, w której Bóg dokonuje „wielkich rzeczy" (Łk 1,49) ${ }^{46}$.

Analizę tę można, a nawet należy, pociągnąć jeszcze dalej. Warto w tym celu przyjrzeć się aspektowi „uniżenia” w kontekście dwóch spotkań Maryi przedzielonych jej pielgrzymką górską ${ }^{47}$, tj. spotkania z aniołem Gabrielem (zwiastowanie) i spotkania z Elżbietą (nawiedzenie). Maryja, tak hojnie obdarowana w scenie zwiastowania,

43 A. Klawek, „Godzina Biblijna”, 106. Dodajmy, że jest to jedyne błogosławieństwo, w kontekście którego w swym komentarzu Klawek wspomina o Maryi, stawiając ją, obok Chrystusa, jako wzór przeżywania tak rozumianego ubóstwa.

44 Zob. A.M. Serra, „Poverty of Spirit”, 10.

45 Zob. A.M. Serra, „Poverty of Spirit”, 11-19.

46 Por. A.M. Serra, „Poverty of Spirit”, 19-24.

47 Warto uzmysłowić sobie, jak wymagająca była ta pielgrzymka: 140-kilometrowa przeprawa górska pokonana w parę dni. Por. B. Adamczewski, „Szczęśliwa, która uwierzyła", 78-79. 
czuje się duchowo zbyt uboga, tj. niegodna tak wielkiego daru, może nawet zażenowana $\left(\delta 1 \varepsilon \tau \alpha \rho \alpha ́ \chi \theta \eta-\right.$, zmieszała się”) ${ }^{48}$. W przeżywaniu tego swoistego duchowego ubóstwa Maryja odczuwa pragnienie pielgrzymki i wyrusza na spotkanie z bliźnim - z Elżbietą. Tu role się odwracają. Teraz Elżbieta doświadcza swego duchowego ubóstwa w spotkaniu z duchowym bogactwem Maryi i doznaje podobnego

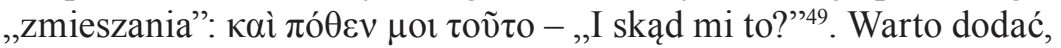
że w identyczny sposób reaguje podczas swojego „zwiastowania”

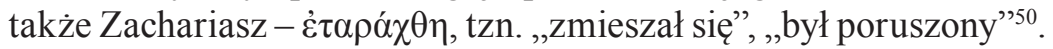

Dochodzimy tu do sedna mariologicznego aspektu ubóstwa, a jednocześnie uświadamiamy sobie, jak ważny jest aspekt mariologiczny dla pełnej interpretacji ośmiu błogosławieństw. Swe duchowe ubóstwo Maryja przeżywa głównie na poziomie osobowego spotkania z Bogiem. Elżbieta przeżywa je w osobowym spotkaniu z Maryją. W rzeczywistości spotkania - ale nie byle jakiego, bo chodzi o spotkanie na drodze pielgrzymki - dostrzec można swoisty mariologiczny paradoks duchowego ubóstwa i bogactwa zarazem.

$\mathrm{Z}$ jednej strony spotkanie wiąże się na początku $\mathrm{z}$ doświadczeniem własnego duchowego niedostatku, uniżenia, zmieszania, zakłopotania, poczucia nieadekwatności do wielkości otrzymanego daru i jednocześnie niezdolności do obdarowania drugiego ${ }^{51}$. Ale z drugiej strony to właśnie spotkanie staje się później źródłem wielkiego bogactwa. Początkowe pełne duchowego ubóstwa „uniżenie” tworzy „płodną przestrzeń”, w której Bóg poprzez swą łaskę i przez

48 GPNT, 240.

49 GPNT, 241.

50 GPNT, 237. Biblijnych przykładów, kiedy to bohater doświadcza tego rodzaju duchowego ubóstwa, tj. ,poczucia niegodności” jest więcej. Dotyczy to np. Dawida, zob.: B. Adamczewski, „Szczęśliwa, która uwierzyła”, 83; por. S. Hahn, „Biblical Theology", 19.

51 Interesującą obserwacją dzieli się w tym temacie Tischner: „Na tym właśnie polega cud spotkania, że człowiek dopiero teraz odkrywa, jak bardzo jest ubogi wobec tego, kogo spotkał. Spotkał i nie ma nic do dania. Cóż może człowiek dać Aniołowi za to, że przyszedł i przyniósł dar? Czym może się odwzajemnić? [...] Dopiero wielkość spotkania ukazała mu niskość. To zwiastowane tak go zubożyło”. J. Tischner, Książeczka pielgrzyma, 14. 
spotkanie z drugim dokonuje ,wielkich rzeczy”, które ostatecznie stają się źródłem duchowego bogactwa (por. 2 Kor 8,1-9).

Warto jeszcze dodać, że Balthasar rozwija w podobnym kontekście mariologiczną teorię ,zawdzięczania siebie drugiemu” w porządku i na obszarze łaski ${ }^{52}$. Tischner zaś powie, że bogactwem, czy też skarbem pielgrzyma, jest spotkany na drodze pielgrzymki zarówno anioł zwiastowania, jak i drugi człowiek ${ }^{53}$.

\section{2. „Błogosławieni, którzy się smucą” (Mt 5,4)}

Rozważania nad tym błogosławieństwem trzeba zacząć od pytania, czy na pewno mowa jest tu tylko o smutku. W tekście oryginalnym

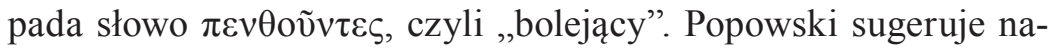
wet dużo mocniejsze, dosłowne tłumaczenie: ,będący w żałobie" 54 . W takim przypadku uzasadniona będzie mowa nie tylko o smutku, ale też o płaczu. Z żałobą związany może być autentyczny płacz, ale - zwłaszcza w kulturach wschodnich - także zawodzenie tzw. płaczek. Różne mogą być więc motywy zmuszające człowieka do zajęcia postawy smutku lub płaczu.

Przychodzą tu na myśl dwie różne kategorie płaczących, jakie znaleźć można na kartach Pisma Świętego. Pierwsza kategoria nawiązuje bezpośrednio do postawy wspomnianych już wcześniej - uciśnionych pod pręgieżem różnych oprawców - starotestamentalnych 'anāwîm. Warto powrócić jeszcze na chwilę do analizy Serry. Zwraca on uwagę, że postawa 'anāwîm najwyraźniej uwidacznia się w narodzie Izraela w sytuacjach niewoli, wygnania i ucisku. Niewola babilońska, a zwłaszcza opresje związane z późniejszą grecką i rzymską okupacją, skłaniają Izraelitów do powrotu do wierności przymierzu, do położenia całej ufności w Bogu oraz do zanoszenia doń pełnych płaczu, ale także ufności modlitw o wyzwolenie ${ }^{55}$. Symbolicznie sytuację tę obrazuje postawa Zuzanny: „Ona zaś, płacząc, podniosła wzrok ku niebu, bo serce jej było pełne ufności w Panu” (Dn 13,35).

\footnotetext{
52 Zob. J. Ratzinger, H.U. von Balthasar, Maryja w tajemnicy Kościoła, 114-122.

53 Por. J. Tischner, Ksiązeczka pielgrzyma, 15.

54 GPNT, 15.

55 Zob. A.M. Serra, „Poverty of Spirit”, 11-17.
} 
Po części odzwierciedlają ją także słowa Psalmu 137: „Nad rzekami Babilonu - tam myśmy siedzieli i płakali, na wspomnienie Syjonu" (Ps 137,1; por. 1 Mch 7,36).

Drugą kategorię stanowi grono płaczących pod krzyżem niewiast. Przypomina się tu Chrystusowe upomnienie skierowane pod ich adresem: „Córki jerozolimskie, nie płaczcie nade Mną; płaczcie raczej nad sobą i nad waszymi dziećmi!" (Łk 23,28). Chrystus nie poleca owym niewiastom, żeby w ogóle nie płakały. Zwraca im jednak uwagę, nad czym należy zapłakać, tj. nie nad skutkiem, ale nad przyczyną ${ }^{56}$.

Nie wiadomo, czy pod krzyżem płakała obecna tam Maryja (J 19,25). Jeżeli tak, to z całą pewnością tej „Córce Syjonu” ${ }^{7}$, bliżej było do pierwszej z opisanych wyżej kategorii, tj. do Zuzanny i do płaczących na wspomnienie Syjonu i proszących Boga o wybawienie ‘anāwîm, niż do wspomnianych wyżej „Córek jerozolimskich”. Jednak tak jak poprzednio ubóstwa, tak teraz smutku czy płaczu nie należy sprowadzać do wymiaru czysto fizycznego. Nie ulega wątpliwości, że Maryja bolała nad tym, co działo się na Golgocie. Niestety ewangeliści nie charakteryzują tego bólu żadnym konkretnym terminem. W każdym razie ważne jest, że Maryi - w przeciwieństwie do płaczek - Chrystus nie musiał upominać, mimo że do niej też osobiście się zwracał (J 19,26).

Nie znaczy to, że Ewangelie całkowicie milczą na temat bólu Maryi. Kwestia ta pojawia się - znowu - w kontekście pielgrzymki. Trzeba się tu odwołać do biblijnej sceny dramatu, jaki przeżyła Maryja wraz z Józefem, szukając Jezusa zagubionego podczas powrotu z pielgrzymki do Jerozolimy ( $\lfloor k 2,41-51)$. Wprawdzie nie pada tu ten sam grecki termin, co w Mt 5,4, ale Maryja oświadcza, że szukała

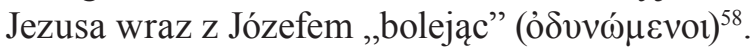

Ciekawą interpretację tego wydarzania proponuje Tischner:

56 Por. J. Tischner, Książeczka pielgrzyma, 21.

57 Por. A.M. Serra, „Poverty of Spirit”, 9. Więcej na temat tego tytułu maryjnego będzie powiedziane w analizie siódmego błogosławieństwa.

58 GPNT, 253. 
Pamiętamy scenę ze świątyni jerozolimskiej. „Synu, cóżeś nam to uczynił? Oto ojciec twój i ja, bolejąc, szukaliśmy ciebie. I rzekł do nich: cóż jest, żeście mnie szukali? Czyż nie wiedzieliście, że w tym, co Ojca mego, być powinienem? Lecz oni nie rozumieli tych słów, które im mówił”. Nawet oni nie rozumieli, a co dopiero my! A jednak w tym, co im Jezus powiedział, była wielka prawda - prawda, którą się osiąga wyłącznie przez dopłakanie. ${ }^{59}$

Mariologiczny aspekt boleści, o której mówi drugie błogosławieństwo, niesie w sobie przesłanie, że są prawdy, których - tak jak Maryja i Józef - nie tylko nie rozumiemy, ale których w czysto spekulatywny sposób nigdy nie zrozumiemy. Są to prawdy, do których dochodzi się jedynie przez „dopłakanie”, czyli prawdy sięgające głębi ludzkiej boleści i ludzkiego cierpienia ${ }^{60}$.

\section{3. "Błogosławieni cisi” (Mt 5,5)}

Analizę trzeciego błogosławieństwa również trzeba rozpocząć od krótkiej refleksji na temat adekwatności powyższego tłumaczenia.

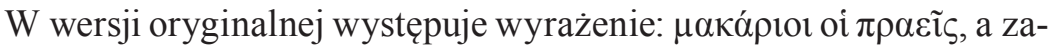
tem w dokładnym tłumaczeniu raczej ,łagodni”"61. O pojęciu ,łagodności” w sposób wyraźny rozprawia na przykład Grzegorz z Nyssy, gdy analizuje to błogosławieństwo ${ }^{62}$.

Łagodność i delikatność to cechy, które zazwyczaj kojarzone są z usposobieniem kobiecym. Nie należy jednak jeszcze na tym poziomie doszukiwać się kontekstu mariologicznego. Trzeba bowiem pamiętać, że nieco dalej w tej samej Ewangelii Jezus określa tym

59 J. Tischner, Książeczka pielgrzyma, 23.

${ }^{60}$ Celem pogłębienia tego zagadnienia warto skonsultować List apostolski Jana Pawła II Salvifici doloris.

${ }^{61}$ GPNT, 15. Zob. też B.T. Viviano, „Ewangelia według św. Mateusza”, 926. Człowiek łagodny i delikatny zazwyczaj nie jest hałaśliwy czy krzykliwy, dlatego aspekt ciszy i milczenia wchodzi bez wątpienia w obręb pola semantycznego przymiotnika $\pi \rho \tilde{\alpha}$ os (por. J. Strong, Grecko-polski słownik, 643) i w zakres tego błogosławieństwa - ważne jest jednak pamiętać, że go nie wyczerpuje.

62 Grzegorz z Nyssy, Homilie do błogosławieństw. Homilia III, 40-46. 


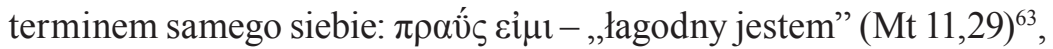
zalecając wszystkim, by Go w tym naśladowali. Po raz kolejny widać wyraźnie, że nie chodzi tu o jakąś fizyczną cechę wrodzoną, lecz o świadomą postawę duchową. Tak rozumiana łagodność, to kolejna cecha 'anāwîm, którzy w cichej i pokornej modlitwie wznoszą swe oczy ku Panu.

Maryjny aspekt takiej postawy łagodności, uprzejmości i pokornego przyjęcia Słowa Bożego wybrzmiewa wyraźnie w scenie zwiastowania (Łk 1,29). Interpretowaliśmy już wcześniej czasownik $\delta ı \tau \alpha \rho \alpha ́ \sigma \sigma \omega$, charakteryzujący zakłopotanie, jakie towarzyszyło wówczas Maryi. Drugi czasownik użyty przez św. Łukasza w tym wersecie opisuje z kolei stan zadumania, w jaki wprawiły Maryję

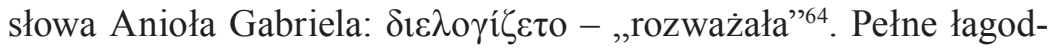
nej zadumy i milczenia rozważanie i przyjęcie (w tym przypadku w sensie dosłowym i przenośnym) Słowa Bożego, charakteryzuje taką właśnie świadomą duchową postawę Maryi ${ }^{65}$.

Ciekawą interpretację tej postawy łagodności i posłuszeństwa Maryi, jako odwrócenia postawy buntu i rebelii, jaką zaprezentować miała Ewa ( $\mathrm{Rdz} 3,6)$, proponuje Hahn. Powołując się na średniowiecznych poetów, pokazuje on na zasadzie gry słów, jak Maryja symbolicznie i dosłownie odwraca to, co Ewa przekazała swym potomnym, i jak słowa zwiastowania łączą się ze słowami, jakie Maryja wypowiada w Kanie (J 2,5):

Średniowieczni poeci zgrabnie podsumowali tę kwestię, wskazując, że Ave (łacińskie powitanie) anioła Gabriela dokonało odwrócenia imienia Eva. Tak samo więc odwróciło ono buntownicze nastawienie Ewy, które pozostawiła ona swym dzieciom - mi i tobie - i zamieniło je na gotowość do posłuszeństwa, którego Maryja chce nas uczyć, kiedy mówi: „Zróbcie cokolwiek wam powie". ${ }^{66}$

63 GPNT, 50.

64 GPNT, 240.

65 C.S. Keener dodaje w swojej interpretacji, że „Maryja wyraża swoją uległość wobec woli Bożej w tradycyjnym starotestamentalnym języku uległości lub milczącej zgody”. C.S. Keener, Komentarz historyczno-kulturowy, 125.

66 S. Hahn, „Biblical Theology”, 18. 
Warto zauważyć ponadto, że w kontekście mariologicznym, tj. we wspominanym już wcześniej „epizodzie” z anonimową niewiastą z tłumu (Łk 11,27-28), Chrystus zdaje się jeszcze raz potwierdzać omawiane tu błogosławieństwo. Dotyczy ono - jak widać - wszystkich, którzy wzorem Maryi, wypełniając jej polecenie z Kany, za-

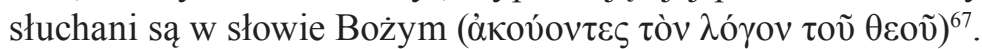

Maryja, która na kartach Ewangelii sama wiele nie mówi, przemawia dużo wyraźniej niż poprzez jakiekolwiek słowa nie tylko swym posłuszeństwem wobec Bożego Słowa, ale także wielorakim czynem: poprzez swą miłość (Łk 2,7), przez współczucie (J 2,3) i przez współcierpienie, które dzielnie znosi podczas całej swej życiowej pielgrzymki, a w szczególny sposób pod krzyżem (J 19,25) ${ }^{68}$.

Mamy tu do czynienia z kolejnym paradoksem mariologicznym wymownym milczeniem. Paradoks ten jest zresztą pochodną analogicznego paradoksu chrystologicznego (Słowo milczące), o którym pisze Balthasar ${ }^{69}$. Tischner słusznie zauważa, że tylko w ciszy głębokiego maryjnego milczenia i skupienia dało się usłyszeć głos obietnicy, który był głosem zwiastowania ${ }^{70}$.

Można jednak w tym momencie zadać pytanie: czy pokorne milczenie nie jest oznaką strachu albo upokorzenia? Odpowiedź brzmi: nie, jeśli tylko znane są prawdziwe motywy takiej postawy. Wyraźnie, właśnie w kontekście błogosławieństwa przysługującego Maryi, mówi o tym Balthasar:

67 Por. B. Adamczewski, „Szczęśliwa, która uwierzyła”, 84-87.

${ }^{68}$ W pięknych słowach ujął to Tischner: „Ile słów wypowiedziała na kartach Ewangelii Matka Chrystusowa? Niewiele. A i te, które wypowiedziała, nie były hałasem. Były raczej skupieniem ciszy, były rozmową, poezją, pokorną prośbą. Im dalej szła historia Ewangelii, tym niej było słów Matki. Pod koniec zamilkła. Nie wiedzielibyśmy, że jest pod krzyżem gdyby nie Syn. Skąd się to brało, że aż tak milczała? Możemy się domyślać - najpierw brało się stąd, że miłość była w Niej większa niż słowo, a potem większe niż słowo było cierpienie”. J. Tischner, Książeczka pielgrzyma, 18.

${ }_{69}$ Zob. H.U. von Balthasar, Medytacja chrześcijańska, 32-39. Por. H.U. von Balthasar, Duch chrześcijański, 88-98.

70 Por. J. Tischner, Książeczka pielgrzyma, 18. 
Pokora Maryi nie jest postawą skruszonej grzesznicy. Jest to radosna, swobodna, dziecięca pokora, której nigdy nie przyszłoby na myśl, że cokolwiek z tego, co w Niej jest, stanowi Jej własność a nie dar Boży. „Błogosławić mnie będą wszystkie pokolenia": już te słowa wskazują na szczególny charakter Jej pokory. ${ }^{71}$

3.4. "Błogosławieni, którzy łakną i pragną sprawiedliwości” (Mt 5,6)

Na początku analizy tego błogosławieństwa, podobnie jak w przypadku pierwszego, zastrzec musimy, że nie wchodzimy w kwestię egzegetycznych hipotez stanowiących o dodaniu przez Mateusza terminu dotyczącego „sprawiedliwości"72. Postaramy się jedynie od strony mariologicznej skomentować biblijny tekst, który mamy

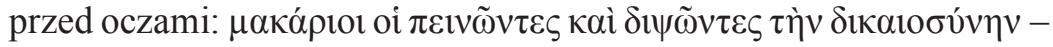
„szczęśliwi łaknący i pragnący sprawiedliwości”73.

Błogosławieństwo ujęte w taką formę, nawiązuje wprost do starotestamentalnej tradycji powtarzającego się - zwłaszcza w Psalmach motywu pragnienia Boga: ,Jak łania pragnie wody ze strumieni, tak dusza moja pragnie Ciebie, Boże!” (Ps 42,2), jak i specyficznego dla tradycji prorockiej wyczekiwania Mesjasza (Zbawcy): „Niebiosa, wysączcie z góry sprawiedliwość i niech obłoki z deszczem ją wyleją! Niechajże ziemia się otworzy, niechaj zbawienie wyda owoc i razem wzejdzie sprawiedliwość! (Iz 45,8). „Ziemia” ma wydać „owoc” - Mesjasza, „różdżkę z pnia Jessego” (Iz 11,1). Owoc ten przyniesie na świat Panna (Maryja) (por. Iz 7,14) ${ }^{74}$. W kontekście mariologicznym powyższe tradycje biblijne ogniskują się w tym, co

71 J. Ratzinger, H.U. von Balthasar, Maryja w tajemnicy Kościoła, 109.

72 Zob. B.T. Viviano, „Ewangelia według św. Mateusza”, 926.

73 GPNT, 16.

74 Nie ma tu oczywiście miejsca na odtwarzanie egzegetyczno-mariologicznej dyskusji dotyczącej mesjanistyczno-mariologicznej interpretacji Iz 7,14. Zainteresowany czytelnik może skonsultować: C. Stuhlmueller, „,The Mother” oraz W. Most, „New Light”. 
popularnie nazywa się w Polsce adwentowym maryjnym nabożeństwem roratnim ${ }^{75}$.

Biblijna sprawiedliwość, o której tu mowa, różni się jednak zdecydowanie od współczesnej, mocno zawężonej percepcji tego terminu. Po raz kolejny trzeba tu odnieść się do kategorii 'anāwîm. To właśnie 'anāwîm reprezentują grono sprawiedliwych w hebrajskim znaczeniu tego słowa, które we współczesnej mentalności europejskiej trzeba by raczej oddać terminem święci. Wyraźnie wskazuje na to w swych analizach Serra, który jako przykład doskonale sprawiedliwych 'anāwîm podaje nam głównych bohaterów pierwszego rozdziału Ewangelii wg św. Łukasza, których dziś nie kojarzy się z wąsko pojętą sprawiedliwością, lecz z szeroko pojętą świętością:

Jak Zachariasz i Elżbieta, Józef i Maryja byli „sprawiedliwi wobec Boga i postępowali nienagannie według wszystkich przykazań i przepisów Pańskich" (por. Łk 1,6). Słowem, odziedziczyli oni to, co najlepsze $\mathrm{w}$ tradycji 'anāwîm. ${ }^{76}$

W tym kontekście nie powinno dziwić, że błogosławieństwo, które tu omawiamy, wybrzmiewa niemal dosłownie w hymnie Magnificat. Można powiedzieć, że Maryja wyśpiewuje tę samą prawdę, którą Chrystus ogłasza podczas Kazania na górze, tylko w nieco

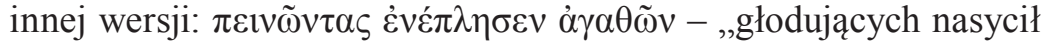
dobrami" (Łk 1,53) 77. Kluczowym łącznikiem pomiędzy obiema tymi wypowiedziami jest tu czasownik $\pi \varepsilon \imath v \alpha ́ \omega$ - „cierpieć głód, niedostatek”, „być w potrzebie, zabiegać"78. Warto zauważyć, że Maryja mówi o nasyceniu łaknących dobrami (w ogólności), a nie na przykład tylko pokarmem. Po raz kolejny oderwać się tu trzeba od fizyczno-materialnej interpretacji i przejść na poziom duchowy - sprawiedliwość może zostać wówczas zakwalifikowana jako jedno z tych dóbr.

75 Nazwa nabożeństwa bierze się od pierwszego słowa łacińskiej wersji cytowanego wyżej tekstu Izajasza w tłumaczeniu Wulgaty: „Rorate, cæli, desuper, et nubes pluant justum" (Iz 45,8).

76 A.M. Serra, „Poverty of Spirit”, 22.

77 GPNT, 243.

78 J. Strong, Grecko-polski słownik, 601. 
Maryja nie jest jednakże tylko tą sprawiedliwą, która przynosi wyczekiwanego „Sprawiedliwego” na ziemię (zasługując przy tym na tytuł Matki Sprawiedliwości). Jej rola nie ogranicza się też do wyśpiewania w Magnificat omawianego tu błogosławieństwa. Ona sama staje się też podmiotem tego błogosławieństwa, podzielając dolę jego adresatów i to w podwójnym sensie.

Najpierw w sensie przenośnym. Skoro w ostatecznym rozrachunku ,sprawiedliwością”, o której mowa w tym błogosławieństwie jest Mesjasz (Chrystus), to „łaknącymi i pragnącymi sprawiedliwości” są ci, którzy szczerze i z determinacją szukają w swoim życiu Boga (Chrystusa). Ona też zmuszona była z wielką determinacją poszukiwać Go, gdy niezauważenie pozostał w świątyni (Łk 2,41-50). Innym razem szukała Go i zmuszona była niemal dopytywać się o Niego, gdy nauczał tłumy (Łk 8,19-20; Mk 3,31-35).

Maryja należy także do tych, którzy łakną i pragną sprawiedliwości sensie dosłownym, tj. wtedy, kiedy doświadcza - jak inni zwykli 'anāwîm - niesprawiedliwości, tzn. pozbawiana jest przynależnych jej dóbr. Do dóbr tych zalicza się np. prawo do posiadania domu, ojczyzny, a przede wszystkim do uszanowania godności drugiego człowieka.

Biblijny wątek mariologiczny jest tu bardzo obszerny, choć tym razem dotyczy nie tylko samej Maryi, ale całej Świętej Rodziny, która musi znosić tułaczkę ( Łk 2,4-5), a w ramach niej odmowę miejsca w gospodzie (Łk 2,7). Następnie przychodzi wygnanie z ojczyzny (Mt 2,13-14) spowodowane niesprawiedliwym wyrokiem wydanym na Dziecię Jezus (Mt 2,16). Całość zamknie się najwyższym aktem niesprawiedliwości w dziejach ludzkości, tj. wyrokiem - tym razem już wykonanym - na jej niewinnym Synu (Mt 27,23-26).

Najważniejsze jest jednak to, że pragnienie sprawiedliwości nie ma tu nic wspólnego z żądzą zemsty czy odwetu ${ }^{79}$. Maryja i Józef, pomimo wielu doznanych krzywd, podejmują z dnia na dzień trud swej pracy i pielgrzymki, nie myślą o zemście, przebaczają i dzięki temu nie ustają $\mathrm{w}$ drodze ${ }^{80}$. Zarysowuje się więc na horyzoncie wątek

79 Por. B.T. Viviano, „Ewangelia według św. Mateusza”, 926.

80 Tischner w swej refleksji dopowiada: „Ile to krzywd wyrządzono prostemu człowiekowi pracy? A człowiek przebaczał, zapominał i szedł pełnić swój codzienny 
przebaczenia, który w sposób naturalny wprowadza nas w obszar zagadnień związanych następnym błogosławieństwem.

\section{5. „Błogosławieni miłosierni” (Mt 5,7)}

Mariologiczny aspekt miłosierdzia wydaje się oczywisty. Matka Miłosierdzia, ostrobramski tytuł maryjny, to - obok Czarnej Madonny, jej jasnogórskiego tytułu - chyba najbardziej znany i najczęściej używany w rodzimej pobożności ,przydomek” Maryi. W ludowej pobożności maryjnej dochodziło niejednokrotnie do niemałych przerysowań i błędów w tytułowaniu Matki Boga. W niektórych oderwanych od Biblii ,tradycjach” Maryja przedstawiana bywała jako Królowa Królestwa Miłosierdzia, podczas gdy Bóg Ojciec a czasem nawet i jej Syn (obdarzony, opacznie rozumianym w tym przypadku, choć w pełni przysługującym Mu, jak widzieliśmy to wyżej, tytułem „Sprawiedliwy”) - sprawować mieli rządy „twardej ręki” w Królestwie Sprawiedliwości ${ }^{81}$.

Każdą refleksję nad miłosierdziem rozpocząć więc trzeba od stwierdzenia podstawowego faktu, że jego źródłem jest Bóg. Maryja zaś - jako „,błogosławiona”, „,pełna łaski” i „,szczęśliwa” - jest tą, która miłosierdzia (w swym niepokalanym poczęciu), łaski Bożej (w dziewiczym poczęciu swego Syna i w swym wniebowzięciu) i prawdziwego szczęścia (w swym Bożym macierzyństwie) doznaje w najpełniejszym stopniu.

Ciekawą biblijno-typologiczną interpretację wspomnianych tu dogmatów maryjnych zaproponował Hahn. W trzech podstawowych kategoriach starotestamentalnych - stworzenia (Ewa), exodusu (Arka) i królestwa Dawida (Królowa-Matka) - widzi on zapowiedź (typ)

obowiązek. Niesiemy to wszystko do stóp Królowej Polski. Niech sprawi, by ci, co łakną i pragną sprawiedliwości byli nasyceni - wedle słów Jej jedynego Syna". J. Tischner, Książeczka pielgrzyma, 28-29.

81 Echa tych ,tradycji” sięgających prac Alfonsa Liguoriego przebijają jeszcze do dziś w niektórych pieśniach maryjnych (np. Serdeczna Matko), a także w postulatach niektórych ruchów ubiegających się o ustanowienie tzw. maksymalistycznych tytułów czy nawet dogmatów maryjnych. Czytelnika zainteresowanego tą problematyką odsyłamy np. do: K. Kowalik, „Piąty dogmat?”, 81-99. 
najważniejszych wydarzeń z życia Maryi (antytyp) i w konsekwencji maryjnych dogmatów ${ }^{82}$.

Tak też w szczególności Ewa, jako pierwsza kobieta żyjąca, od pierwszej chwili swego osobowego istnienia w stanie nadprzyrodzonego daru łaski uświęcającej ( $R d z 2,15-25)$, jest w tym ujęciu typem niepokalanie poczętej, łaski pełnej Maryi (Łk 1,28) ${ }^{83}$. Nietykalna Arka (Lb 1,51; 1 Krn 13,10), która nosi w sobie wyryte w kamieniu słowo Boże $(2$ Krn 5,10) i wstępuje w bramy świętego miasta Jeruzalem (1 Krn 15,1-16,43), jest typem nieskalanej Dziewicy (Łk 1,27), która nosi w sobie wcielone Słowo Boże (Łk 1,31-35) i wstępuje w świątynne bramy niebieskiego Jeruzalem (Ap 11,19-12,1) ${ }^{84}$. Wreszcie Maryja, jako Boża Rodzicielka (Łk 2,6-7), tj. Matka Mesjasza-Króla $(\mathrm{Iz} 7,14)$ z rodu Dawida (Łk 1,32), staje się Królową-Matką, antytypem starotestamentalnej Gebirah, a w konsekwencji Królową nieba (Regina caeli), czyli nowego wiecznego Królestwa swojego Syna $^{85}$. Dalszej interpretacji tych dogmatów w wymiarze chrystologicznym dokonuje Balthasar, wskazując na niezwykle głęboki związek dogmatów o niepokalanym i dziewiczym poczęciu $\mathrm{z}$ - odpowiednio - ludzkim i Boskim aspektem dogmatu chalcedońskiego ${ }^{86}$.

Nie trzeba oczywiście zgadzać się ze wszystkimi szczegółami interpretacji zaproponowanych przez zacytowanych tu teologów. Jedno pozostaje jednak pewne: wszystkie te wydarzenia, ogniskujące się jak w soczewce w życiu Maryi i sformalizowane przez Tradycję i Magisterium Kościoła w postaci maryjnych dogmatów, są doniosłym

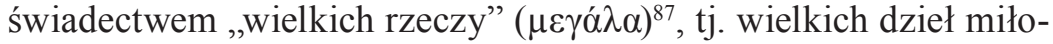
sierdzia Bożego, jakich dokonał Bóg w życiu i osobie Maryi, o których z wdzięcznością śpiewa ona w hymnie Magnificat (Łk 2,46-55).

82 Por. S. Hahn, „Biblical Theology”, 14.

83 Por. tamże, 17.

${ }^{84}$ Por. tamże, 18-21. W tym kontekście Hahn dokonuje ciekawego zestawienia okrzyku Elżbiety w chwili nawiedzenia jej przez Maryję (Łk 1,42) z okrzykami i śpiewami jakie towarzyszyły przenoszeniu Arki przymierza (1 Krn 15,28; 16,4-5; 2 Krn 5,13).

85 Por. S. Hahn, „Biblical Theology”, 22-26.

86 Zob. J. Ratzinger, H.U. von Balthasar, Maryja w tajemnicy Kościoła, 53-69, 91-94.

87 GPNT, 242. 
Warto podkreślić, że spośród wielu różnych terminów greckich, jakie można zastosować, aby wyrazić rzeczywistości miłosierdzia i łaski, w hymnie tym dwukrotnie wybrany zostaje rzeczownik $\varepsilon^{\prime} \lambda \varepsilon \circ \varsigma$ (Łk 1,50.54), który posiada wspólny słowotwórczy rdzeń z terminami występującymi w omawianym błogosławieństwie: $\dot{\varepsilon} \lambda \varepsilon \eta ́ \mu o v \varepsilon \varsigma-$, ,itościwi” oraz $\dot{\varepsilon} \lambda \varepsilon \eta \theta \eta ́ \sigma o v \tau \alpha$ - „litości doznają"88. W języku hebraj-

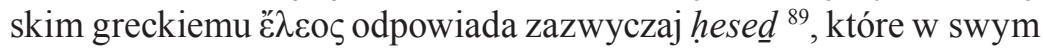
bogatym polu semantycznym zawiera nie tylko znaczenia związane z łaską i miłosierdziem, ale także cierpliwością, wiernością, solidarnością, słusznością, trwaniem w przymierzu, a niekiedy nawet sprawiedliwością ${ }^{90}$.

Jeśli połączy się rozważania dotyczące mariologii obecnego i poprzedniego błogosławieństwa, można zauważyć, że Maryja jednocześnie wysławia sprawiedliwość Bożą i Boże miłosierdzie, przez co niejako osobiście dystansuje się od wspomnianych wyżej tendencji, starających się rzeczywistości te sobie przeciwstawiać. W jej hymnie, niczym w hebrajskim hesed, obie z przywołanych rzeczywistości współgrają ze sobą. Przekłada się to na kolejny, choć tym razem tylko pozorny, paradoks mariologiczny: Maryja zasługuje w dokładnie takim samym stopniu na tytuł Matki Sprawiedliwości, co na tytuł Matki Miłosierdzia.

W omówieniu poprzedniego błogosławieństwa dokonaliśmy przeciwstawnego zestawienia pragnienia i łaknienia sprawiedliwości z żądzą zemsty i odwetu. Warto pójść dalej w tym kierunku i zestawić teraz miłosierdzie z jego przeciwieństwem. Na pewno nie będzie to sprawiedliwość, gdyż to właśnie przeciwieństwo miłosierdzia (a nie miłosierdzie!) leży u podstaw wszelkiej niesprawiedliwości. Niepotrzebne kontrastowanie sprawiedliwości z miłosierdziem bierze się, być może, z niewłaściwej identyfikacji rzeczywistego

88 GPNT, 16.

89 Por. J. Swetnam, „Hesed w Starym Testamencie”, 251-260.

90 Przykładowym miejscem, w którym Septuaginta tłumaczy hesed nie tylko

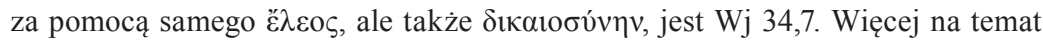
analizy egzegetycznej tego wersetu oraz pola semantycznego hebrajskiego ḥesed w: J. Lemański, „JHWH - Bóg”, 19-43; J. Seremak, „Paradygmat zbawczej obecności”, 150-156. 
przeciwieństwa miłosierdzia. Prawdziwym przeciwieństwem miłosierdzia jest bowiem okrucieństwo.

Wyraźnie poucza nas o tym na kartach Biblii właśnie Maryja, która zmuszona znosić niewyobrażalne trudy ucieczki do Egiptu, pobytu tam i powrotu do ojczyzny (Mt 2,13-15.19-23), doświadczyła na sobie konsekwencji okrucieństwa Heroda, które doprowadziło go do wydania tak skrajnie niesprawiedliwego wyroku na niewiniątka $\left(\right.$ Mt 2,16) ${ }^{91}$.

\section{6. „Błogosławieni czystego serca” (Mt 5,8)}

Podstawowym zagadnieniem łączącym szóste błogosławieństwo z mariologią jest oczywiście motyw serca ( $\alpha \rho \delta i ́ \alpha)$. Mariologiczna refleksja nad tym problemem zdaje się rozwijać dwutorowo. Typowy przykład tej dwutorowości widoczny jest w podejściu Ronalda Bagleya.

$\mathrm{Z}$ jednej strony problematyka serca Maryi wpisuje się w głęboko biblijny nurt refleksji nad Maryją w omawianym już wcześniej szerokim kontekście 'anāwîm, tj. ubogą w duchu, łagodną i cichą służebnicą Pańską, która ,zachowywała wszystkie te sprawy i rozważała je w swoim sercu" (Łk 2,19; por. Łk 2,51). Bagley podejmuje w tym kontekście głęboką refleksję Augustyna na temat zrodzenia Chrystusa przez Maryję nie tylko za pośrednictwem łona, lecz przede wszystkim za pośrednictwem serca: „Boże macierzyństwo nie byłoby owocne dla Maryi, gdyby wcześniej nie porodziła Chrystusa z większą radością i korzyścią w swym sercu niż w swym łonie"92. Myśl ta wpisuje się w omawiane wcześniej kategorie paradoksu „refleksywnej cykliczności” oraz interpretacyjnej przewagi-w kontekście błogosławieństw - duchowych aspektów życia Maryi nad aspektami materialnymi (por. kwestie ubóstwa, płaczu, łagodności).

Jednak z drugiej strony zupełnie innym torem rozwija się od wieków maksymalistyczny nurt mariologiczny, podpinający się często

91 Do tego samego wniosku, choć zupełnie inną drogą dochodzi Tischner, który swym rozważaniom na temat tego błogosławieństwa nadaje znamienny tytuł Miłosierdzie i okrucieństwo. J. Tischner, Książeczka pielgrzyma, 31-34.

92 Por. R.M. Bagley, „The Heart of Mary”, 131. 
pod kontekst - całkowicie słusznego skądinąd - nabożeństwa do Niepokalanego Serca NMP. Nurt ten stawia sobie za cel rozwijanie tytułów maryjnych i nadawanie sercu Maryi rangi zrównującej go nie tylko w sensie czci, ale nieraz nawet w sensie dosłownym z Sercem Zbawiciela. Chodzi tu więc o przerysowania analogiczne do tych, o których była już mowa w kontekście błogosławieństwa dotyczącego miłosierdzia. Dla przykładu, Bagley, powołując się na prace XVII-wiecznego francuskiego mariologa Jeana Eudesa, zdaje się twierdzić, a przynajmniej powielać jego twierdzenia, iż: „Jezus żyje i króluje w Sercu Maryi do tego stopnia realnie, że można powiedzieć jest On Sercem Maryi”93, czy też: „Serce Jezusa i Serce Maryi są jednym i tym samym Sercem" "94. Przeprowadzone tam próby wyprowadzania tego typu twierdzeń z chrystologicznych tekstów biblijnych (J 15,4; J 17.21-23) nie wydają się być trafne $i$ można się zastanawiać, czy są dla mariologii pożyteczne ${ }^{95}$.

Dużo bardziej owocne - w kontekście rozważanego obecnie błogosławieństwa - będzie pogłębienie refleksji w kierunku biblijno-mariologicznego tytułu „służebnicy Pańskiej” (Łk 1,38). Czystość serca, zgodnie z obietnicą zawartą w tym błogosławieństwie, pozwala na oglądanie Boga. Należy sobie więc postawić pytanie: jaka maryjna postawa otwiera nas na tę zdolność? Odpowiedź kryje się właśnie w postawie służebnicy. W tekście oryginalnym pada tu termin $\delta o v ́ \lambda \eta$, który - jak sugeruje Popowski - można tłumaczyć nawet jako „niewolnica”"96. Warto zauważyć, że właśnie z tytułem „służebnicy" Maryja wiąże w Magnificat swój tytuł najściślej łączący ją z ośmioma błogosławieństwami tj. $\mu \alpha \kappa \alpha \rho i ́ \alpha$ (por. Łk 1,48).

Bardzo ciekawą refleksję nad omawianym tytułem maryjnym proponuje Balthasar. Zauważa on tutaj kolejny mariologiczny paradoks.

93 R.M. Bagley, „The Heart of Mary”, 132.

94 R.M. Bagley, „The Heart of Mary”, 133.

95 Więcej na temat tego typu przerysowań w: K. Kowalik, „Per Mariam ad Iesum”, 25-30. W opracowaniu tym autor zauważa, że w podejściu maksymalistycznym dochodzi czasem niemalże do wyścigów na tytuły, w których Maryja ma nie tylko dorównywać Chrystusowi, ale nawet go prześcigać: „Pobożność maryjna w opisywanym tu aspekcie to taka właśnie równość Chrystusa i Maryi ze wskazaniem na Maryję". Tamże, 28.

96 GPNT, 240. 
Maryja poprzez to i dzięki temu, że jest służebnicą (a nawet jeszcze lepiej: niewolnicą!), staje się królową (nieba, aniołów, pokoju, Kościoła itd. $)^{97}$. Jako królowa nieba, Maryja z całą pewnością ogląda Boga. Na tytuł królowej zasługuje jednak o tyle, o ile gotowa była przyjąć tytuł służebnicy/niewolnicy.

Postawa służby jest zatem receptą na to, by wzorem Maryi móc w rzeczywistości swojego życia oglądać Boga oraz odczytywać Jego wolę i oczekiwania. Tischner doda tu jednak jeszcze jeden ważny warunek. Jest to wbrew pozorom właśnie warunek czystości serca. Polega on na usunięciu motywu ciekawskości, który zanieczyszcza nasze intencje i przesłania nasz duchowy wzrok:

Chcesz wiedzieć, czego Bóg oczekuje dziś od nas? Zastanów się i zobacz, jaki jest dziś nasz obowiązek. Ale nie zobaczysz i nie zrozumiesz niczego, jeśli chodzić ci będzie wyłącznie o zaspokojenie ciekawości. Dopiero wtedy zobaczysz, gdy powiesz: „,..pytam, aby służyć”. 98

Powyższa refleksja nasuwa na myśl pewną uwagę, wyjątkowo chyba aktualną w czasach obecnych. Tak przyziemne terminy jak „służba” i „obowiązek” zdają się być niezwykle odległe od wyżyn „duchowych uniesień”, z którymi zazwyczaj próbuje się wiązać wszelkiego rodzaju mistyczne doświadczenia związane z oglądaniem Boga. Nie chcąc w żaden sposób negować ani podważać wartości autentycznego doświadczenia mistycznego, należy zauważyć, że naświetlony tu Maryjny aspekt oglądania Boga, który polega na wiernym wypełnianiu swojego, być może nawet najbardziej prozaicznego, obowiązku (jak chociażby życie codzienne w Nazarecie), powinien być drogowskazem dla wszystkich tych, którzy sądzą, że Boga znaleźć lub zobaczyć można jedynie w emocjonalnych uniesieniach czy też różnego rodzaju pozanaturalnych zjawiskach.

97 Zob. J. Ratzinger, H.U. von Balthasar, Maryja w tajemnicy Kościoła, 87-89.

98 J. Tischner, Książeczka pielgrzyma, 38. 


\section{7. „Błogosławieni, którzy wprowadzają pokój” (Mt 5,9)}

Idąc tropem rozważań dotyczących poprzednich kilku błogosławieństw, także i tutaj moglibyśmy zacząć od wspomnienia adekwatnego do tej tematyki maryjnego tytułu Królowej Pokoju. Do tego też nawiążemy, ale wcześniej będzie nas interesował inny mariologiczny tytuł, głęboko osadzony w tekstach biblijnych, bo sięgający swymi korzeniami Starego Testamentu.

Wprowadzanie pokoju, zgodnie z obietnicą zawartą w omawianym

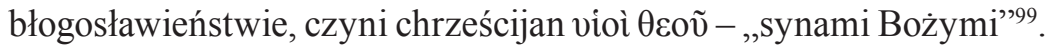
Maryja zapowiada tę rzeczywistość i sama już w niej partycypuje

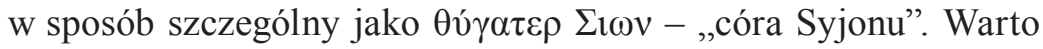
przytoczyć tu adekwatny werset z proroka Sofoniasza w całości, by móc zauważyć jak głęboko licuje on zarówno z pozdrowieniem anielskim, jak i z Magnificat: „Wyśpiewuj, Córo Syjońska! Podnieś radosny okrzyk, Izraelu! Ciesz się i wesel z całego serca, Córo Jeruzalem!" (So 3,14) ${ }^{100}$.

Ci, którzy wprowadzają pokój, stają się ,synami Bożymi” i ,córkami Syjonu”, tj. tymi, którzy dostępują radości życia w Bogu. Głęboką refleksję nad tym zagadnieniem podjął Ratzinger, wracając w tym kontekście właśnie do sceny zwiastowania:

„Raduj się" - dlaczego Maryja może się radować w takim świecie? Odpowiedź brzmi: „Pan jest z Tobą”. Chcąc zrozumieć sens tego zwiastowania, musimy ponownie zajrzeć do podstawowych dla niego tekstów Starego Testamentu, zwłaszcza do Sofoniasza. Zawsze zawierają one podwójną obietnicę dla Izraela, córy Syjonu: Bóg przyjdzie jako Zbawca i w niej zamieszka. Rozmowa anioła z Maryją nawiązuje do tej obietnicy i dokonuje podwójnej jej konkretyzacji. To, co prorocze słowa mówią o córze Syjonu, odnosi się teraz do Maryi: zostaje Ona utożsamiona z córą Syjonu, jest nią w swej własnej osobie.

99 GPNT, 16.

${ }^{100}$ Obszerny opis historii badań nad korelacją omawianych tu tekstów znaleźć można w: N. Lemmo, „Maria, «Figlia di Sion»”. W temacie tym warto też

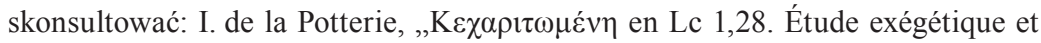
théologique". 
I równolegle do tego Jezus, którego ma zrodzić Maryja, zostaje utożsamiony z Jahwe, Bogiem żywym. ${ }^{101}$

Innymi słowy, jeśli oprzemy się na powyższych rozważaniach, możemy obecne błogosławieństwo sparafrazować w następujący sposób: błogosławieni, którzy wprowadzają pokój, albowiem oni stają się synami w Synu i córkami w Córce.

Wróćmy jednak do zagadnienia pokoju. To, że Maryja jest explicite

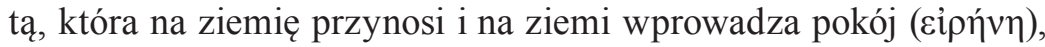
o którym mówi siódme błogosławieństwo, najpełniej wybrzmiewa poprzez jej Boże macierzyństwo. W kontekście pierwszych odwiedzin, jakie składają Maryi i nowonarodzonemu Jezusowi pasterze (Łk 2,8-20), rozbrzmiewa w anielskich głosach zapowiedź „,pokoju

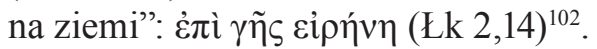

Bezpośrednio po odwiedzinach pasterzy Łukasz przechodzi do sceny ofiarowania (Łk 2,21-38), podczas której pada słynne proroctwo Symeona. Maryja przyniosła na ziemię pokój, więc starzec

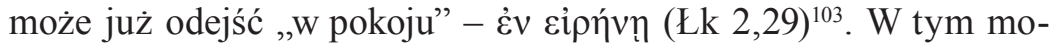
mencie dochodzi do swoistej sztafetowej zmiany pokoleń. Symeon wprawdzie odchodzi w pokoju, ale Maryi przekazuje w swym proroctwie ,pałeczkę niepokoju”, którą jest jego osławiony „,miecz” (Łk 2,35). Dochodzimy tu więc do odkrycia kolejnego mariologicznego paradoksu. Maryja, Królowa Pokoju, ma być jednocześnie tą, której serce przeszyje miecz niepokoju. Pokój, który przynosi światu Maryja, trzeba bowiem rozumieć nie w światowych kategoriach: „Czy myślicie, że przyszedłem dać ziemi pokój? Nie, powiadam wam, lecz rozłam" (Łk 12,51).

Problematyka „miecza Symeona” wprowadza nas bezpośrednio w następne błogosławieństwo.

${ }^{101}$ J. Ratzinger, H.U. von Balthasar, Maryja w tajemnicy Kościoła, 56. Więcej w tym temacie: J. Ratzinger, Córa Syjonu.

102 GPNT, 248.

103 GPNT, 250. 


\section{8. „Błogosławieni, którzy cierpią prześladowanie dla sprawiedliwości" (Mt 5,10)}

Ostatnie błogosławieństwo rozpatrywane w kontekście mariologicznym spina swoistą klamrą radosno-charytologiczny tytuł maryjny „łaski pełna” - a zatem też, jak to zostało ustalone wcześniej, „,szczęśliwa” ( $\mu \alpha \kappa \alpha \rho i ́ \alpha)$ - z tzw. problematyką , miecza Symeona” (Łk 2,35), czyli z będącym przedmiotem tego błogosławieństwa „cierpieniem prześladowań".

Głęboką refleksję podejmują nad tym wysoce paradoksalnym zagadnieniem zarówno Ratzinger, jak i Balthasar ${ }^{104}$. To właśnie teolog niemiecki dostrzega tę niebywałą syntezę, jaka zachodzi pomiędzy „,raduj się”, które słyszy Maryja w chwili zwiastowania, a „mieczem współcierpienia", jaki przeszywa ją pod krzyżem:

Ponieważ jednak życie człowieka zawsze jest cierpieniem, dlatego obraz cierpiącej Matki, obraz rahamim Boga, nabrał dla chrześcijaństwa tak wielkiego znaczenia. W Niej dopiero dosięga kresu obraz Krzyża, ponieważ Ona, jest przyjętym i we współcierpieniu niesionym Krzyżem, którzy pozwala nam w Jej współcierpieniu doświadczać współcierpienia Boga. Tak więc ból Matki jest bólem paschalnym, który otwiera już przemianę śmierci we właściwe miłości zbawcze bycie z drugim. Pozornie tylko oddaliliśmy się przy tym od „raduj się”, od którego rozpoczyna się historia Maryi. Bo zwiastowana Jej radość nie jest radością banalną, zapominającą o otchłani naszego bytu, a tym samym skazaną na spadnięcie w próżnię. [...] Autentyczna jest tylko taka radość, która stawia czoło cierpieniu i jest od niego mocniejsza. ${ }^{105}$

Podczas omawiania piątego błogosławieństwa zauważyliśmy, że Maryja w swym Magnificat wychwalała Boży ḥesed/eleos, tj. wierne ojcowskie miłosierdzie. Ratzinger zauważa z kolei, że sama w swoim życiu realizowała to drugie, komplementarne, matczyne oblicze

${ }^{104}$ Zob. J. Ratzinger, H.U. von Balthasar, Maryja w tajemnicy Kościoła, 65-69, 94-96.

105 Tamże, 68. 
miłosierdzia, wyrażane zazwyczaj biblijnymi terminami rahamîm/ oiktirmos, cechujące się pełną współczującej i współcierpiącej miłości troską, a zarazem tym wyjątkowym rodzajem radości, jaką przeżywa kobieta zaraz po przezwyciężeniu cierpień związanych z bólami rodzenia (por. J 16,20-22).

Teolog szwajcarski dostrzeże w tym kontekście wezwanie podjęte przez Maryję, ale skierowane również do każdego chrześcijanina, do ciągłego wzrastania i oczyszczana swej wiary w ogniu cierpień i prześladowań:

Sens tego nieprzerwanego wychowywania Maryi do czystej wiary i do stania pod Krzyżem często nie jest dostatecznie rozumiany. Stajemy zdumieni i zakłopotani wobec sposobu, w jaki Jezus obchodzi się ze swą Matką, do której zarówno w Kanie, jak i pod Krzyżem zwraca się per „Niewiasto”. On sam, jako pierwszy, wywija mieczem, który musi Ją przeniknąć. Gdyby tego nie czynił, w jaki sposób mogłaby jednak dojrzeć? Jak mogłaby trwać pod Krzyżem, gdzie oczywista wydaje się nie tylko ziemska porażka Jej Syna, ale również opuszczenie Go przez posyłającego Ojca? ${ }^{106}$

Rozważania te uzupełnia Tischner, który - pogłębiając poczynione wyżej rozróżnienie pomiędzy łaknieniem sprawiedliwości a żądzą odwetu - podejmie refleksję nad różnicą, jaka dzieli nieszczęście od krzyża. Ktoś, kto koncentruje się w swoim życiu na roztrząsaniu nieszczęść i krzywd, które go spotkały, zatrzymuje się w miejscu, staje się z czasem niewolnikiem odwetu i w konsekwencji przestaje pielgrzymować. Tymczasem pielgrzym potrafi dostrzec różnicę pomiędzy użalaniem się nad nieszczęściem, a pełnym miłości niesieniem krzyża ${ }^{107}$. W tym właśnie kontekście również i Tischner

106 Tamże, 96.

${ }^{107}$ Różnicę tę Tischner ujmuje następująco: „Krzyż to coś nieskończenie więcej niż nieszczęście. Krzyż jest świadectwem. Świadectwo to głosi: istnieją wartości mocniejsze i wyższe od tych, z których ogałaca nas nieszczęście. «Duszy zabić nie mogą». Tak, istnieje nieprzekraczalna granica przemocy. Jest coś, czego «zabić nie mogą». Tam właśnie należy umieścić swą miłość, bo «...gdzie jest skarb twój, tam jest serce twoje»”. J. Tischner, Książeczka pielgrzyma, 41. 
nawiąże do problemu „miecza Symeona”, zauważając nierozerwalnie złączone ze sobą dwa jego oblicza: mariologiczne i chrystologiczne.

Ile razy przychodzi nieszczęście, wiemy: mogłoby być inaczej. Mogłoby nie być trzęsienia ziemi, wylewu rzeki, gradu. O krzyżu tak powiedzieć nie można. Ten kielich trzeba wypić do dna. „A duszę twoja własną przeniknie miecz, by wyszły na jaw zamysły serc wielu” - powiedział Symeon do Maryi. ,Jeśli ziarno nie obumrze, nie wyda owocu" - powiedział Chrystus. ${ }^{108}$

Powyższy cytat można uogólnić, podsumowując jednocześnie całość przeprowadzonych tu rozważań: otóż chrystologiczne oblicze ośmiu błogosławieństw nierozerwalnie związane jest i odbija się, niczym w perfekcyjnym zwierciadle, w ich obliczu mariologicznym.

\section{Głoszenie Królestwa Bożego}

Na wstępnie zaznaczyliśmy, iż celem niniejszej pracy nie są tylko teoretyczne analizy tekstów związanych z ośmioma błogosławieństwami i z postawą życiową Maryi. Chcemy, żeby praca ta miała również swoje przełożenie na wymiar pastoralno-duszpasterski.

Tekst błogosławieństw Mt 5,3-10 został tak zredagowany, aby jego motywem przewodnim stało się zagadnienie Królestwa Bożego - choć jest formalnie obecne w klamrze kompozycyjnej jedynie w pierwszym i ostatnim błogosławieństwie, to merytorycznie obejmuje całość perykopy. Głoszenie Królestwa Bożego i wzywanie do nawrócenia są zresztą nadrzędnymi motywami całego Kazania na górze ${ }^{109}$.

Problematyka ta jest też centralną (trzecią) tajemnicą części modlitwy różańcowej, którą wprowadził Jan Paweł II, obejmującej tzw. tajemnice światła ${ }^{110}$. Omawiając te tajemnice, papież podzielił się

108 Tamże, 41.

109 Por. B.T. Viviano, „Ewangelia według św. Mateusza”, 925-938.

${ }^{110}$ Omawiając trzecią tajemnicę światła, papież pisał: „Tajemnicą światła jest nauczanie Jezusa, w czasie którego głosi On nadejście Królestwa Bożego i wzywa do nawrócenia". Zob. Jan Pawłeł II, List apostolski Rosarium Virginis Mariae, 21. Do kwintesencji tego nauczania Jezusa należy z całą pewnością osiem błogosławieństw. 
następującą refleksją, dotyczącą ich jako całości: „W tych tajemnicach, z wyjątkiem Kany, obecność Maryi pozostaje ukryta w tle" "111.

Papież jasno zaznacza, że Maryja jest obecna we wszystkich tych tajemnicach. Można się domyślać, że teologom pozostawił zadanie podjęcia badawczego trudu, żeby z tego tła wydobyć jej postać ${ }^{112}$.

Zadanie to zdaje się podejmować w swej pracy Casarella. Słusznie sugeruje on, że słowa Maryi z drugiej tajemnicy światła: „Zróbcie wszystko, cokolwiek wam powie" (J 2,5), są bezpośrednim echem słów samego Boga Ojca z pierwszej i czwartej tajemnicy: „Ten jest mój Syn umiłowany, w którym mam upodobanie” (Mt 3,17) oraz „To jest mój Syn umiłowany, Jego słuchajcie!” $(\mathrm{Mk} 9,7)^{113}$. W kontekście piątej tajemnicy, słowa Maryi współbrzmią ze słowami Chrystusa, który tym razem już sam nakazuje swym uczniom: „to czyńcie na moją pamiątkę!" (Łk 22,19).

Pozostaje nam zadać pytanie: co z trzecią tajemnicą? Casarella wykazuje się tu dobrą intuicją, bo wyczuwa, że trzeba pójść w kierunku błogosławieństw. Rozważając trzecią tajemnicę, pisze: „tajemnica ta przywołuje błogosławieństwo: «błogosławieni, którzy wprowadzają pokój»" "114. Nie podając jednak uzasadnienia, ogranicza się on tylko do tego jednego błogosławieństwa.

Tymczasem, żeby dostrzec, jak bardzo aspekt Maryjny wybrzmiewa w słowach Chrystusa również w tej tajemnicy, należy spojrzeć na błogosławieństwa całościowo - właśnie w kontekście

111 Jan Pawłeł II, List apostolski Rosarium Virginis Mariae, 21.

112 Przez ostatnie dwie dekady zarówno na gruncie rodzimym, jak i międzynarodowym, powstała duża ilość prac naukowych i popularnonaukowych, poświęconych mariologicznej refleksji nad tajemnicami światła. Spośród tych, które wpisują się w przyjęte tu ramy rozważań biblijno-mariologicznych, warto wspomnieć o opracowaniach autorów, do których już wcześniej nawiązywaliśmy, tj. do Kudasiewicza i Langkammera (J. Kudasiewicz, Nowe tajemnice oraz H. Langkammer, Dlaczego), o historyczno-biblijnie ukierunkowanym opracowaniu Jerome'a Vereba (J. Vereb, Pope John Paul II) oraz o dogłębnie biblijnie i patrystycznie - choć już nie mariologicznie - osadzonej refleksji Tima Graya (T. Gray, The Luminous Mysteries). Warto wreszcie dodać, że i Balthasar pozostawił po sobie głębokie medytacje nad tajemnicami różańca świętego (H.U. von Balthasar, Różaniec), jednak siłą rzeczy nie mogły objąć one swym zasięgiem tajemnic światła.

113 Por. P. Casarella, „Contemplating Christ”, 167.

114 Tamże, 166. 
przeprowadzonej w niniejszej pracy ich mariologicznej interpretacji. Oczywiście, podobnie jak w przypadku pozostałych tajemnic, Maryja pozostaje i powinna pozostać tutaj w tle. Niemniej jednak warto pokazać, jak bogate jest to tło i jak bardzo mariologiczna refleksja może wzbogacić chrystologiczne rozważania nad tą tajemnicą.

W tym celu odnieść trzeba się do analizy przeprowadzonej przez Gérarda Rosségo, który - rozważając omawianą tajemnicę w kontekście problematyki Królestwa Bożego zwrócił uwagę na dwa istotne aspekty tego podstawowego pojęcia biblijnego:

a. Królestwo Boże jako miejsce, do którego wchodzą ci, którzy potrafią się odmienić i stać się jak dzieci (Mt 18,3),

b. Królestwo Boże jako zapowiedź nowego porzadku, który radykalnie zrywa z porządkiem biegu świata doczesnego ${ }^{115}$.

W kontekście niniejszej pracy, pierwszy aspekt nawiązuje do szeroko omówionego tu wymiaru pielgrzymujących 'anāwîm, którzy - jako „maluczcy” - pielgrzymując przez swoje życie drogą ośmiu błogosławieństw, wchodzą przez wąską bramę do owego Królestwa. Ten aspekt, jak już zaznaczaliśmy na wstępie, nie jest nowością i nie brakuje też opracowań tajemnic różańcowych, odwołujących się do tej ,pielgrzymiej” tematyki ${ }^{116}$.

Dużo ciekawszy z punktu widzenia niniejszych rozważań jest drugi aspekt. Nowy porządek Królestwa Bożego różni się do tego stopnia od porządku, jaki panuje w królestwach tego świata, że sprawia on wrażenie całkowitej paradoksalności. Całe życie Maryi - jak również życie każdego, kto na poważnie postanowi kroczyć drogą ośmiu błogosławieństw - poprzecinane było na wskroś licznymi paradoksami. Nie było wbrew pozorom ,elegancko poukładane”, jak sugerują to niektóre „nader sentymentalne” interpretacje.

Analizy przeprowadzone w niniejszej pracy wykazały wyraźnie, że w jej życiu było miejsce na spokój i łagodność, ale też na pośpiech i ekstremalne trudy pielgrzymek, było miejsce na harmonijne wyśpiewywanie miłosierdzia i sprawiedliwości oraz na doświadczanie

115 Por. G. Rossé, „The mysteries of light”, 18-20.

116 Zob. np. S. Szczepaniec, Rekolekcje oraz M.B. Pennington, 20 tajemnic różańca. 
okrucieństwa i niesprawiedliwości, było wreszcie miejsce na wielką radość, ale co chwilę przeszywaną mieczem cierpienia.

\section{Zakończenie}

Z całą pewnością w tej pracy nie zostały wyczerpane wszystkie mariologiczne aspekty tematyki ośmiu błogosławieństw, zwłaszcza jeżeli chodzi o zastosowanie przeprowadzonych tu analiz w bliższych praktyce dziedzinach teologii. Tego typu kompletność nie była ambicją jej autora. Podstawowym celem artykułu było pobudzenie współczesnej refleksji teologicznej w sektorze badań, który posiada ogromny (choć zdaniem autora nie wystarczająco jeszcze wykorzystany) potencjał rozwojowy, a który określić można mianem mariologii biblijnej.

Zaproponowane lub jedynie zasygnalizowane tu obszary zastosowań na polu nowej ewangelizacji, nowego feminizmu, rozważań tajemnic różańcowych czy choćby na - podkreślonym tu za Tischnerem, ale bynajmniej nie wyczerpanym - polu refleksji nad teologią pielgrzymki, tak głęboko wpisanym z jednej strony w pobożność maryjną, a z drugiej w rzeczywistość ośmiu błogosławieństw, z całą pewnością mogą stać się wdzięcznymi tematami dalszych pogłębionych i poszerzonych analiz.

Motywem przewodnim przedstawianej tu mariologiczno-biblijnej refleksji była myśl Benedykta XVI, który ewangeliczne błogosławieństwa uznał za nowy program życia chrześcijańskiego. Do realizacji tego programu wzywa chrześcijan zaproponowana przez Jana Pawła II trzecia tajemnica światła. Rozważania zawarte w niniejszej pracy można uznać za konkretną propozycję realizacji tego programu w świetle biblijnie udokumentowanego doświadczenia życiowego i osobowości Maryi.

Na zakończenie warto więc wyciągnąć z przedstawionych analiz osiem syntetycznych wniosków, które wskazują, jak - naśladując Maryję na własnej życiowej drodze ośmiu błogosławieństw - można proklamować we współczesnym świecie Królestwo Boże:

1. Przez ubóstwo Maryi, które - mimo że przeżywane również na poziomie materialnym - osiąga swój szczyt w pokorze i w potrzebie spotkania zarówno z aniołem zwiastowania, jak 
i z drugim człowiekiem (Elżbieta). Takie ubóstwo otwiera na przyjęcie daru i w konsekwencji staje się źródłem prawdziwego bogactwa.

2. Przez ból Maryi, który - skonfrontowany z płaczem niewiast - uczy nas, że sensowny jest tylko płacz nad przyczyną, a nie nad skutkiem oraz że są prawdy, których nie można poznać przez dociekanie, lecz jedynie przez „dopłakanie”.

3. Przez łagodność Maryi, która pokazuje, że codziennym pokornym i radosnym czynem (Nazaret), współczuciem (Kana) i współcierpieniem (Golgota), można powiedzieć wiele więcej niż nieprzebranym, hałaśliwym potokiem słów.

4. Przez pragnienie i łaknienie sprawiedliwości, którymi jest przepełnione życie Maryi, a które nie mają nic wspólnego z żądzą zemsty i odwetu. Kto oddałby się zemście za doznane krzywdy, zatrzymałby się w drodze i przestałby pielgrzymować.

5. Przez maryjne doświadczenie Bożego Miłosierdzia i ludzkiego okrucieństwa, które - zwłaszcza w kontekście zbrodniczego wyroku Heroda - uświadamia, że prawdziwym przeciwieństwem miłosierdzia nie jest sprawiedliwość, lecz okrucieństwo.

6. Przez czystość serca Maryi, która polega przede wszystkim na wolności od postawy ciekawskości i zdolności oglądania Boga uzyskanej dzięki sumiennemu wykonywaniu obowiązków służebnicy, która w ten właśnie sposób staje się królową.

7. Przez zewnętrzny i wewnętrzny pokój, jaki panuje w sercu Maryi, którego nie należy mylić ze zwykłym spokojem i który nie jest ,pokojem” tego świata, lecz pokojem tych, którzy w Chrystusie stają się „,synami w Synu”, a w Maryi „córkami w Córce".

8. Przez „miecz Symeona” przenikający serce Maryi, słyszącej przy zwiastowaniu słowa „raduj się” i wskazujący na to, że autentyczna jest tylko taka radość, która nie obawia się stawić czoła cierpieniu i jest od niego mocniejsza. 


\section{Podziękowania}

Autor pracy pragnie wyrazić podziękowania ks. dr. hab. Bartoszowi Adamczewskiemu, prof. UKSW, za cenne uwagi i wskazówki, które w znacznej mierze przyczyniły się do pogłębienia i poszerzenia zawartych w niej analiz.

\section{Mariological Interpretation of the Eight Beatitudes (Mt 5:3-10)}

Abstract: The article examines the question of the Mariological interpretation of the eight beatitudes contained in Mt 5:3-10. Christian theologians of all ages, from Clement of Alexandria to the authors of contemporary biblical commentaries, have proposed various interpretations of this biblical text. Among the multitude of interpretations developed throughout history, the Mariological aspect appears quite rarely. Yet, as Pope Benedict XVI observes, the very biblical Marian title "Blessed" should direct the theological thought to the Mariological aspects of this issue. In modern times, a very deep reflection on the subject was conducted by two great theologians of the XX century, J. Ratzinger (Benedict XVI) and H.U. von Balthasar. On the Polish ground, the task was partly undertaken by J. Tischner, who elaborated the theme of eight beatitudes in the key of the Marian pilgrimage of the nation. The present work is meant to deepen the Mariological-biblical analysis of the eight beatitudes and revive the discussion regarding this subject in the perspective proposed by Benedict $\mathrm{XVI}$, to understand the beatitudes as a program of life for a modern Christian.

Keywords: eight beatitudes, Mariology, pilgrimage, Benedict XVI (Josef Ratzinger), Hans Urs von Balthasar, Józef Tischner

\section{Bibliografia}

Adamczewski, B., „Szczęśliwa, która uwierzyła (Łk 1,45)”, Verbum vitae 5 (2004), 75-87.

Augustyn z Hippony, O kazaniu Pana na Górze. Do Symplicjana o różnych problemach. Problemy ewangeliczne, S. Ryznar, J. Sulowski (tłum.), Warszawa 1991.

Bagley, R.M., „The Heart of Mary, Model of Love: Marian Dimension of the Millennium Preparation", Marian Studies 50 (1999), 127-138.

Balthasar, H.U. von, Duch chrześcijański, Z. Włodkowa (tłum.), Poznań 2013. Balthasar, H.U. von, Medytacja chrześcijańska, W. Szymona (tłum.), Poznań 2014.

Balthasar, H.U. von, Różaniec: zbawienie świata w modlitwie maryjnej, Jan Koźbiał (tłum.), Wrocław 1998.

Barzun, J., The Culture We Deserve: A Critique of Disenlightenment, Middletown (CT) 1989. 
Kudasiewicz, J., Mastalska, D., Biblijna droga pobożności maryjnej. Z księdzem profesorem Józefem Kudasiewiczem rozmawia Danuta Mastalska, Kielce 2002.

Buby, B.A., Biblical Methodology and Mariology. The Use of Bibical Methodologies in Marian Theology Today, https://udayton.edu/imri/mary/b/biblical-methodology-and-mariology.php (dostęp 16.05.2020).

Casarella, P., ,Contemplating Christ through the eyes of Mary: The Apostolic Letter Rosarium Virginis Mariae and the New Mysteries of Light", Pro Ecclesia: A Journal of Catholic and Evangelical Theology 14 (2005) nr 2, 161-173.

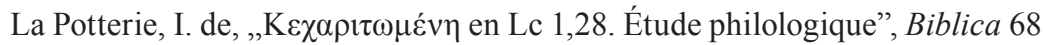
(1987), 357-382.

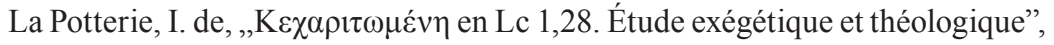
Biblica 68 (1987), 480-508.

Dodd, G.F., „Feminist and New Feminist Perspectives on Mary: Renewal or Retrieval?", Marian Studies 65 (2014), 277-327.

Fausti, S., Wspólnota czyta Ewangelię wedtug św. Mateusza, Częstochowa 2007. Feuillet, A., Jésus et sa mère : d'après les récits lucaniens de l'enfance et d'après saint Jean : le rôle de la Vierge Marie dans l'histoire du salut et la place de la femme dans l'Église, Paris 1978.

Gray, T., The Luminous Mysteries: Biblical Reflections on the Life of Christ, Steubenville 2005.

Grecko-polski Nowy Testament. Wydanie interlinearne z kodami gramatycznymi [GPNT], R. Popowski, M. Wojciechowski (tłum.), Warszawa 2003.

Gryglewicz, F., Błogosławiona przez wszystkie narody Matka Boża w Nowym Testamencie, Częstochowa 1984.

Grzegorz z Nyssy, Homilie do błogosławieństw, M. Przyszychowska (red.), Kraków 2005.

Hahn, S., „Biblical Theology and Marian Studies”, Marian Studies 55 (2004), 9-32.

Häring, B., Pieśń stugi; Błogosławieństwa; Eucharystia, A. Mysłowska, A. Łobocka-Oleksowicz, M. Mroszczak (tłum.), Warszawa 1982.

Jan Paweł II, Encykliki Ojca Świętego Jana Pawła II, Kraków 2006.

Jan Paweł II, Listy apostolskie Ojca Świętego Jana Pawła II, Kraków 2007.

Katechizm Kościoła Katolickiego, Poznań 1994.

Viviano, B.T., „Ewangelia według świętego Mateusza”, w: R.E. Brown, J.A. Fitzmyer, R.E. Murphy (red.), W. Chrostowski (red. nauk. wyd. pl.), Katolicki Komentarz Biblijny, Warszawa 2018.

Keener, C.S., Komentarz historyczno-kulturowy do Nowego Testamentu, K. Bardski, W. Chrostowski (red. nauk. wyd. pl.), Warszawa 2010.

Klawek, A., „Godzina Biblijna - Osiem Błogosławieństw”, Ruch Biblijny i Liturgiczny 20 (1967) nr 2, 103-109. 
Klemens Aleksandryjski, Kobierce zapisków filozoficznych dotyczących prawdziwej wiedzy, t. 1-2, J. Niemirska-Pliszczyńska (red.), Warszawa 1994.

Kowalik, K., „Per Mariam ad Iesum. Per lesum ad Mariam”, Salvatoris Mater 3 (2001) nr 2, 22-33.

Kowalik, K., „Piąty dogmat?”, w: tegoż (red.), Tradycja i otwartość. Księga pamiątkowa ku czci O. prof. S.C. Napiórkowskiego, Lublin 1999, 81-99.

Langkammer, H., Dlaczego różańcowe Tajemnice Światta?: medytacje biblijne, Wrocław 2012.

Langkammer, H., Maryja w Nowym Testamencie, Gorzów Wielkopolski 1991.

Lemański, J., „JHWH - Bóg, który przebacza, gdyż jest miłosierny (Wj 34,5-7)”, Verbum vitae 18 (2010), 19-43.

Lemmo, N., „Maria, «Figlia di Sion» a partire di Lc 1,26-38: Bilancio esegetico dal 1939 al 1982", Marianum 45 (1983), 175-258.

Manelli, S.M., All generations shall call me Blessed: biblical mariology, New Bedford (MA) 1995.

Manelli, S.M., Mariologia biblica, Frigento 1989.

Most, W., „New Light on the Messianic-Marian Character of Isaiah 7:14”, Miles Immaculatae 25 (1989) nr I-II, 54-67.

Neumann, C.W., „The Decline of Interest in Mariology as a Theological Problem", Marian Studies 23 (1972), 12-38.

Orygenes, Komentarz do Ewangelii według Mateusza, K. Augustyniak (tłum.), E. Stanula (red.), Kraków 1998.

Pennington, M.B., 20 tajemnic różańca: podróż biblijna, J. Ruszkowski (tłum.), Poznań 2004.

Pinckaers, S.T., „Komentarz św. Augustyna do Kazania na górze”, w: tegoż, Źródła moralności chrześcijańskiej, A. Kuryś (tłum.), Poznań 1994.

Ratzinger, J. (Benedykt XVI), Balthasar, H.U. von, Maryja w tajemnicy Kościoła, W. Szymona (tłum.), Kraków 2007.

Ratzinger, J. (Benedykt XVI), Błogosławieństwa sq nowym programem życia, Rozważanie przed modlitwą „Anioł Pański” 30.01.2011, https://opoka.org. pl/biblioteka/W/WP/ benedykt_xvi/modlitwy/ap_30012011.html (dostęp 16.05.2020).

Ratzinger, J. (Benedykt XVI), Córa Syjonu: Maryja w refleksji Kościoła, B. Widła (tłum.), Warszawa 1997.

Ratzinger, J. (Benedykt XVI), Jezus z Nazaretu, cz. 1, W. Szymona (tłum.), Kraków 2007.

Ratzinger, J. (Benedykt XVI), Verbum Domini. Posynodalna adhortacja apostolska o słowie Bożym w życiu i misji Kościoła, Poznań 2010.

Ratzinger, J. (Benedykt XVI), Wprowadzenie w chrześsijaństwo, Z. Włodkowa (tłum.), Kraków 1996. 
Riches, A., „Deconstructing the Linearity of Grace: The Risk and Reflexive Paradox of Mary's Immaculate Fiat", International Journal of Systematic Theology 10 (2008) nr 2, 179-194.

Rinaldi, B., La Madonna nella fede tra le donne moderne. Per una rielaborazione della teologia femminile, Milano 1996.

Rondet, H., Maria nel disegno di Dio: Giuseppe l'uomo delle beatitudini, Roma 1966.

Rossé, G., „The mysteries of light”, Living City 42 (2003) nr 5, 18-20.

Rossier, F., „Kecharitomene (Lk. 1:28) in the Light of Gen. 18:16-33: A Matter of Quantity", Marian Studies 55 (2004), 159-183.

Samiec, Ł., Maryja i „preferencyjna opcja na rzecz ubogich”, Kraków 2019.

Seremak, J., „Paradygmat zbawczej obecności wyzwolenia: imię Boga Ehjeh-Jhwh, «Jestem-On jest» (Wj 3,14-15 / Wj 34,6-7)”, Studia Bobolanum 29 (2018) nr 2, 141-161.

Serra, A.M., E c'era la Madre di Gesù... (Gv. 2,1): saggi di esegesi biblico-mariana (1978-1988), Milano 1989.

Serra, A.M., „Poverty of Spirit and the «Marvelous Deeds» of God as Seen in Mary's Magnificat: Reflections from the Hebrew Scriptures", Marian Studies 50 (1999), 8-37.

Siwiński, N.M., „Rogamus te, Domina nostra - sześć modlitw maryjnych św. Antoniego z Padwy jako świadectwo mariologii franciszkańskiej XIII wieku", Collectanea Theologica 86 (2016) nr 3, 91-145.

Strong, J., Grecko-polski słownik Stronga z lokalizacją słów greckich i kodami Popowskiego, A. Czwojdrak (tłum.), Warszawa 2015.

Stuhlmueller, C., „The Mother of Emmanuel (Is. 7:14)”, Marian Studies 12 (1961), 165-204.

Swetnam J., „Hẹesed w Starym Testamencie a eleos w Nowym”, Ruch Biblijny i Liturgiczny 51 (1998) $\mathrm{nr}$ 4, 251-260.

Szczepaniec, S., Rekolekcje „na różańcowym szlaku”: tajemnice światta, Kraków 2015.

Tischner, J., Ksiażeczka pielgrzyma, Warszawa 1996.

Tomasik, P., „Katecheza maryjna dzieci i młodzieży szkolnej. Źródła, zakresy tematyczne, zasady", Collectanea Theologica 89 (2019) nr 2, 159-182.

Van der Merwe, I.J., „Biblical happiness and baptismal identity”, Stellenbosch Theological Journal 1 (2015) nr 2, 695-710.

Vereb, J., Pope John Paul II and the Luminous Mysteries of the Rosary, New Jersey (NJ) 2003.

Wołowski, L., „Słowo o syntezie zasad Per Mariam ad Iesum i Per Iesum ad Mariam", Salvatoris Mater 77-80 (2018), 254-263.

Życiński, W., Matka, która pozostała Dziewica, Kraków 2017. 